Article

\title{
Nature Interpretation and Visitor Management Objectives: A Survey of Tourist Attitudes at Maasai Mara National Reserve, Kenya
}

\author{
Leanard Otwori Juma ${ }^{1}\left(\mathbb{D}\right.$, Izabella Mária Bakos ${ }^{2}$ and Aniko Khademi-Vidra ${ }^{2, *}$ \\ 1 Institute of Tourism and Hospitality Management, Dedan Kimathi University of Technology, \\ Nyeri 10143, Kenya; leanard.juma@dkut.ac.ke \\ 2 Faculty of Economics and Social Sciences, Szent István University, 2100 Gödöllő, Hungary; \\ bakos.izabella.maria@gtk.szie.hu \\ * Correspondence: Khademi.Vidra.Aniko@gtk.szie.hu
}

Received: 29 July 2020; Accepted: 2 September 2020; Published: 4 September 2020

\begin{abstract}
Nature interpretation has been advocated as a soft and non-obtrusive on-site visitor management strategy to enhance visitor knowledge and understanding of the resource, mitigate visitor impacts, encourage the conservation and improvement of attraction areas, and assist visitors in enjoying their visit. However, the way in which nature interpretation programs are implemented, and the subsequent attitudes created amongst visitors can pose a challenge to the effectiveness of nature interpretation as a visitor management strategy. The situation becomes more complicated with limited resources to implement, monitor, and evaluate nature interpretation in expansive wilderness areas like Masai Mara National Reserve (MMNR). The question therefore is, does nature interpretation in MMNR create favourable attitudes amongst wildlife tourists, consequently leading to enhanced visitor experiences and satisfaction of the support for conservations, or not? This research, therefore, sought to establish the extent to which the attitudes created by nature interpretation affect visitor satisfaction or the enhanced visitor experience and support for conservation, broadly termed as visitor management objectives in MMNR Kenya. Thus, $\mathrm{H}_{\mathrm{o}} 1$ postulated that attitudes created by nature interpretation do not influence visitors' support for conservation in $\mathrm{MMNR}$, and $\mathrm{H}_{\mathrm{o}} 2$, that attitudes created by nature interpretation do not enhance visitor experience and satisfaction in MMNR. This study used a structured questionnaire for the survey to collect data from a sample of 351 respondents as a proportion of visitors into MMNR. Research findings revealed that a moderate relationship between attitudes created by nature interpretation and support to conservation with $r_{s}=0.426$ and $p=0.000$, thus null hypothesis ${ }^{H_{0}}{ }^{1}$ was rejected. Secondly, results showed that attitudes created by nature interpretation moderately affected visitor satisfaction $r s=0.478$ and $p=0.000$, while similarly, null hypothesis $\mathrm{H}_{0}{ }^{2}$ was rejected. The research concluded that various forms of NI result in the formation of attitudes that moderately affect support for conservation and visitor satisfaction. The study concluded that enhanced nature interpretation training and awareness creation, along with continual improvement initiatives, could unlock its full potential as a visitor management strategy. This consistent, well-coordinated, and diligent implementation of nature interpretation initiatives by all stakeholders in MMNR would sustain a cumulative, long-term impact.
\end{abstract}

Keywords: nature interpretation; visitor codes; orientation signage; tour guiding; visitor management; Maasai Mara

\section{Introduction}

It has been argued that tourism and conservation areas have intimately been related for centuries and that driving, walking, or travelling to experience nature-based attractions has continuously been a 
vital component of the operations of nature-based destinations over the years [1]. Research carried out in Germany's Jasmund National Park established that nature-based tourism is among the rapidly-growing segments in contemporary tourism markets [2], a trend that has been echoed by the United Nations World Tourism Organization (UNWTO) [3,4]. Consequently, given that tourism in conservation areas is heavily dependent on the quality of in-situ cultural and natural resources, the impacts of visitation must be managed carefully, directed, and mitigated wherever possible by all stakeholders for sustainability. It has been observed that the type of management adopted by a tourist destination will mainly depend on the values and objectives it seeks to pursue and that proactive planning of tourism development and visitor management will promise their realisation [5-7]. This is because, whereas changes in the resource as a result of visitor use are inevitable, they might be desirable, and therefore, to mitigate these, destination managers are compelled to influence the behaviour of resource users and consequently, the tourism induced impacts [7]. Visitor management is therefore considered to be part of destination management in protected areas and destinations keen on sustainable tourism; it has never been a function of high visitor numbers, but always been part of any destination or attraction $[8,9]$.

Olson et al. [10], McArthur \& Hall [11], and Van der Donk [12] define visitor management as the summation of all practices and programs implemented to ensure visitors realise quality experiences while concurrently supporting the realisation of a destination area's aggregate conservation objectives. This definition evokes three essential elements about visitor management, which is to safeguard and augment the resource, help guests enjoy their visit, and sustain and expand the economic benefits that tourism can bring [13]. Visitor management initiatives such as site hardening, safety barriers, information centres, provisions of visitor adequate and suitable amenities are envisioned to not only protect the resource from further negative impacts, but also to enhance the quality and diversity of destination experiences. On the other hand, visitor management initiatives like the provision of maps and orientation signage, visitor information, safety and safety and risk management strategies, are thought to enhance a visitor's experience. Lastly, approaches like tour guiding services will create local jobs and additional visitor experiences for a fee.

Candrea \& Ispas [14] opine that the visitor management techniques available to managers of nature-based destinations include: regulating tourist use by zoning; seasonal pricing to control the type of visitation; differentiated entry or user fees; restricting access to only accredited organisations or individuals to bring visitors to the site; provide nature interpretation programmes and facilities; and lastly, visitor behaviour regulation using codes of conduct. The current study will focus on the last two visitor management techniques, and these are nature interpretation and behaviour regulation. Nature interpretation has been defined as an educational activity that endeavours to reveal meanings and interrelationships through the use of objects, firsthand experiences, or by illustrative media, rather than by merely communicating factual information $[13,15,16]$. Ham \& Sandberg, and Ham et al. [17] assert that as a visitor management strategy, nature interpretation chooses and delivers messages while appreciating the impact this communication can have on protected areas and its visitors. Nature interpretation constitutes personal forms like tour guiding services and non-personal forms such as codes of conduct, display boards, maps, and orientation signage.

Research carried out in Australia by Eagles et al. [1] supports the opinion that nature interpretation can be used as a non-obtrusive visitor management strategy. This research appreciates that regardless of the type or form, nature interpretation as a strategy assists visitor management at the site level because "... it represents a link between the resources and the visitors ... making areas accessible and delivers insights to visitors about the place [2], while acknowledging the range of stakeholders involved" [18]. Further to these, research carried out at Kinabalu Park in Malaysia reveals that there is an increasing demand for guiding services and educational information at interpretation centres [19-22]. Positive attitudes amongst both the visitors and interpretative service providers (tour guides and managers) are critical for the success of forms of nature interpretation as a strategy for conservation area visitor management. Given these, nature interpretation should endeavour to create favourable attitudes amongst its users. 
In Kenya, research carried out in Mombasa Marine Park and Reserve identified nature interpretation as a tool that can influence the actions or inactions of resource users, and thereby affecting the management of marine resources [23]. In recognition of the impact nature interpretation can have in visitor management, the Nairobi Safari Walk, for instance, has been appreciated as one of the supreme nature-based tourism and conservation education facility in Kenya with diverse and detailed interpretive services [24]. Contrary to these, however, other attraction sites and museums have step-on guides that are poorly regulated and mainly provided by freelancers and trainees with little attention given as to their professional skills and competencies [25-27]. Further to this, Ikiara \& Okech [28] identified inadequate nature and cultural interpretation of natural tourist attractions as one of the challenges facing the tourism industry in Kenya and that environmental regulations are either disregarded or ineffectively implemented. Indeed, according to Adeola and Aderemi Ayinla [29], this unfortunate scenario has also been replicated in Nigeria. Edinborough et al. [19] observe that ad hoc approaches drive the provision of interpretative services considerably in some nature conservation areas. This observation acknowledges that in some conservation areas, interpretative services are unplanned or lack adequate emphasis by the relevant stakeholders.

MMNR is one of Kenya's well-kept secrets and one of the most famous national reserves in Africa and indeed the world. The rolling savanna grasslands receive regular rainfall that supports a large and diverse selection of herbivores, predators, and birdlife. As a biodiversity hotspot, MMNR is famous for nature-based tourism activities like game drives, balloon safaris, camping, and birding, among others. Globally, there is increased demand for nature-based tourism destinations $[3,4,30]$ like MMNR that receive hundreds of thousands of visitors annually. Thus, the sustainability of natural resources like the MMNR ecosystem that tourism highly depends on requires visitor information, education, and interpretation to better manage the tourists and potential impacts thereof $[12,26]$.

Although stakeholders have touted forms of nature interpretation as some of the best non-obtrusive on-site visitor management strategies, unfavourable attitudes pose a challenge to the effectiveness of types of nature interpretation as visitor management strategies. It is especially so amongst its direct users and visitors, tour guides, and relevant visitor managers. The issue becomes more complex as the application of forms of nature interpretation in visitor management is an intricate task that must involve many interests and different stakeholders to address the diverse objectives thereof effectively. Indeed, earlier researchers have identified inadequate interpretation of natural tourist attractions as one of the challenges facing Kenya's tourism industry [28]. Visitor management through different forms of nature interpretation in Masai Mara National Reserve (MMNR) is characterised by low coordination and a lack of commitment amongst tourism operators and the County Government of Narok, with each having different visitor management priorities. While the County Government of Narok is keen to sustainably conserve the reserve and sustainable tourism utilisation, tourism operators are interested in customer satisfaction.

The visitor management situation in MMNR is compounded further by the existence of several freelance tour guides providing interpretative services, albeit with wanting competences and minimal regulation. Even though nature interpretation is an effective form of communication in such a scenario, its ability to create favourable visitor attitudes for the realisation of desired visitor management objectives in MMNR is questionable. This study sought to establish the extent to which nature interpretation influences visitors' attitudes towards the support for conservation, and enhanced visitor experience and satisfaction in MMNR.

\section{Literature Review}

\subsection{The Call for Visitor Management and the Place of Nature Interpretation}

Over the years, the United Nations World Tourism Organisation (UNWTO) has reported and projected sustained and steady tourism growth globally $[3,4,30]$. This tourism growth trend has indeed been replicated and reported in most regions, destinations, or tourist market segments 
around the world. For instance, contemporaries in Germany have observed that nature-based tourism is among the fastest-growing market segments [2]. Similarly, Eagles et al. [1], Frost, Laing, and Beeton [31], Chen and Prebensen [32], in their researches on tourism and conservation areas in East Asia, observed that the global travel in the contemporaries marketplace is growing. Besides, they continue to add that journeys are not only swelling, but also that holiday travel to nature-based destinations like parks, reserves, and similar conservation areas are also tremendously increasing. In this regard, therefore, as visitor numbers grow, so do the management challenges thereof.

It could be argued that, in most cases, visitors are unaware of the fact that this type of behaviour might be impacting negatively on the environment. Actions including casual damage to sensitive areas; exploring areas of fragile biodiversity; littering; feeding wild animals; moving too close to wild animals (harassment); removal of souvenir pieces; making noise; vandalising vegetation and graffiti on-site have significant impacts on the environment [6,14,32-38]. Unpleasant tourists' behaviour may be attributed partly to a lack of visitor management and information provision. In this regard, therefore, it calls for careful management of visitor experiences that must minimise harmful impacts at attractions, while at the same time maximising enjoyment, understanding, and appreciation of the resource through satisfactory and suitable access, and nature interpretation.

On the other hand, Sharpley $[35,39,40]$ asserts that visitor management is a necessary evil in a sense. That is, inasmuch as tourists enjoy the liberties and impulsiveness that holiday affords them to an extent, visitor management imposes some restrictions on that freedom. In essence, some of these restrictions are seen as essential for the sustainability of destination resources upon which tourism depends, but may also preserve visitor safety and welfare, albeit appearing to curtail visitor freedom on the face value. In this regard, visitor management becomes necessary to mitigate the potential negative impacts of tourism activities, while at the same time enhancing visitor comfort and safety by minimising potential hazards and risks to visitors. Nevertheless, ideally, visitor management should be unobtrusive, non-regulatory, and able to heighten visitor experiences.

On a similar note, Bhati \& Pearce [41] and Kuo [42] observe that hard visitor management strategies are primarily suitable for short-term results in visitor negative impacts management. However, hard visitor management strategies applied alone might not realise long-term outcomes because they have obstructive aspects. Scholars support the opinion that conservation education or nature interpretation as a soft visitor management strategy ought to be applied to compliment hard management strategies [13,41,43-45]. These researchers, as endorsed by other earlier scholars, observe that nature interpretation elaborates the reasons behind regulatory actions like zone closures or limiting the number of visitors is necessary and, indeed, the implications of inappropriate behaviour $[1,19]$

According to Bhati and Pearce [41], Alazaizeh and Hallo [43], and Durao and Joao Carneiro [45], they relentlessly endorse nature interpretation as a visitor management technique that assists with site management; it represents a link between the resources and the visitors. Likewise, Albrecht [13] and Sterry [27] assert that nature interpretation is a necessary and practical component of a tourism planner's tool kit. In essence, a well-designed focused and presented nature interpretation has a critical role in enhancing visitor experiences and satisfaction, mitigating visitor impacts, and encouraging positive behaviour towards nature conservation.

Indeed, conservation education and nature interpretation are fundamental tools used by managers in attraction and destination areas to regulate visitors to attractions in a non-intrusive or non-obstructive manner better, thereby reducing negative impacts while increasing the positive effects $[13,32,34,38-40,46]$. Furthermore, nature interpretation raises general awareness that will lead to support for resource management policies and agencies. On a similar note, Mason [47], Alazaizeh and Hallo [43], and Bhati \& Pearce [41], all affirm that diligent application of nature interpretation programs significantly enhances the visitor experiences, thus making the attraction area more competitive. Indeed, nature interpretation is not the same as information provision. Whereas the later provides facts about phenomena, the former, on the other hand, endeavours to reveal concepts, meanings, and the interrelationships that exist within the wonders of mother nature. In this regard, therefore, 
nature interpretation educates the visitor about his new environment and enhances the experience thereof $[19,48]$. The guided tours provided to visitors, nature interpretation information contained on display boards, visitor codes, and orientation signage not only enhance the understanding that tourists get at the destination but also healthier interactions and satisfaction.

Nevertheless, the values and attitudes of visitors are changing; they now demand more environmentally responsive services and products, as well as information [25]. Indeed, these sentiments have been echoed by Durao and Joao [45] and Juma [16], observe that visitors want to learn about the environment they visit and also want to understand the connections with a broader ecosystem. Nature interpretation can be a treasured tool to intensify conservation awareness and appreciation amongst tourists and site-level tourism operators, depending on these nature conservation areas. Nature interpretation also illustrates how tourists and site-level tourism operators can support the conservation and sustainability of natural and cultural resources upon which they may depend for non-consumptive utilisation today and into the future.

Studies by Farrell and Marion [49] identify minimising visitor impacts, evaluation, and public involvement and shared learning as some of the objectives in visitor management through nature interpretation. More inclusively, Raasch [2] supports the argument that various forms of nature interpretation have a variety of goals and benefits for conservation, as well as to visitor enjoyment. In other words, different kinds of nature interpretation enhance visitor knowledge and understanding (educational activity), improve visitor experiences (recreational activity), and support conservation.

Nonetheless, nature interpretation is not always successful. Scholars have identified some of the reasons why nature interpretation may not realise its full potential as a tool for visitor management $[41,44,45]$. However, the full potential can only be realised after understanding how to use nature interpretation as a tool. Other challenges can present themselves as impediments to achieving these potentials. These include a lack of creativity in the implementation of nature interpretation, lack of an evaluation culture, and limited training on destination visitor management objectives [50]. In light of increasingly higher numbers of visitations UNWTO [3], Albrecht [13], Bhati and Pearce [41], Hovardas et al. [18], Donk and Cottrell [51], Sterry [27] and Van der Donk [12] stress that education, interpretation, and information are vital tools used by administrators to manage visitors better. For instance, in Kenya, nature-based tourism, also referred to as wildlife tourism, is the largest segment and accounts for over $90 \%$ of nature-based tourism and nearly $75 \%$ of aggregate tourism earnings $[16,52,53]$. In conclusion, the literature reviewed indicates that nature interpretation, as a visitor management strategy, enhances visitor knowledge and understanding, supports conservation, and enhances visitor experiences. Hence, the current research considered the latter two elements as key indicators (herein referred to as visitor management objectives) of visitor management through nature interpretation in the Masai Mara National Reserve. Generally, nature interpretation is a communication strategy that simplifies how visitors interacts with the spatial areas visited. Indeed, scholars describe nature interpretation as an educational activity, a communication process, or a management tool [17]), to practice stimulating and encouraging appreciation [19].

On the other hand, Tilden [15], as cited in Raasch [2] and Carranza et al. [35], Juma [16], notes that nature interpretation is an educational activity that aims to reveal meaning and interrelationships through the use of real objects, firsthand experiences or by illustrative media, rather than communicating factual information. Tilden [15] continues to assert that interpretation provokes curiosity and interest. It relates to everyday experiences of visitors, reveals a memorable message, and addresses the whole story using a unifying theme [7,14,16,20,36,44-46,54]. Ceballos-Lascuráin [55], Edinborough et al. [19], Hansen \& Fowler [56], and Borges \& Ronda [57] assert that not having a nature interpretation program in a conservation area is akin to inviting guests into your abode and then vanishing. In this regard, the role of various forms of nature interpretation is first to make visitors more conscious of the spaces and places they visit $[16,26,45]$. Secondly, nature interpretation provides information to guests that increase their understanding and consequently stimulating interest, that will result in grander enjoyment and possibly responsible behaviour amongst visitors within the visited site $[10,13,14,18,55]$. 
Ham and Sandberg [17] assert that, when nature interpretation successfully provokes individuals to have independent thinking and to attach separate meanings about an object or place, it helps in shaping that person's experience with an entity or site if these thoughts are pleasing or gratifying, thereby enhancing a person's experience.

Undeniably, regardless of the type or form, nature interpretation as a visitor management technique assists in site management as it represents a link between the resources and the visitors and make places accessible and provide visitors with insights into a site [2]. Nevertheless, nature interpretation is a component of contemporary conservation area management planning in Kenya [58]. Some of the forms of nature interpretation found in Kenya's attraction sites include the printed word (maps, guidebooks, pamphlets), tour guiding services, visitor codes of conduct, and orientation signage. Further to these interpretative displays (storyboards or audiovisual displays) are visitor centres, mechanical or interactive devices, and more [24]).

\subsection{Theoretical and Conceptual Framework}

Fishbein and Ajzen [59] define an attitude as the tendency to respond to an object with some degree of favorableness or un-favorableness. In other words, attitudes are likes and dislikes or a tendency to react either negatively or positively towards a specific person, object, idea, or situation. Elaboration-Likelihood Theory (E.L.M.) propounded by Cacioppo et al. [60] explains the diverse ways in which a person evaluates the information $\mathrm{s} /$ he receives. Sometimes a person may assess messages elaborately through critical thinking, while on other occasions through a more straightforward and less significant manner [61]. Therefore, Elaboration likelihood is defined as a variable and can range from poor to excellent as the likelihood of elaborate thoughts on a phenomenon depends on the way an individual processes a received message and involves the cognitive and affective domains of attitudes [62,63]. E.L.M. studies carried out by Ham \& Sandberg [17] established that an interpretive encounter provoking more thinking would result in more robust and enduring attitudes and resultant behaviour patterns. That is, any communication which successfully stimulates an audience into critical thinking stands a better chance of affecting attitudes than a conversation that does not provoke thought. This persuasion theory is relevant to this study because forms of nature interpretation are persuasive communication: tour guiding services, maps, orientation signage, and visitor codes of conduct.

Nature interpretation presented to visitors in MMNR was postulated to create an understanding of the issues and interrelationships that exist amongst phenomena in the wild and how they affect or can be affected by wildlife viewers' actions or inactions. As a technique for presenting nature and cultural information, nature interpretation generates understanding, herein referred to as the cognitive domain of attitudes; consequently, this understanding shapes the affective domain by creating the liking or disliking of the phenomena, and ultimately, the affective domain shapes the behavioural intentions and behaviour displayed by the visitors while interacting with the flora, fauna, landscape, and other aspects of MMNR. In this regard, tour guiding as a nature interpretation technique not only helps tourists to identify natural and cultural phenomena, but will also reveal why things are the way they are, the interrelationships therein, and their relevance to the environment and society. Visitor information and orientation signage as another technique similarly helps wildlife viewing participants to make responsible decisions, and navigate safely to their destinations. Lastly, visitor codes of conduct, also referred to as rules and regulations, prescribe the appropriate and desired behaviour and actions presented as do's and don'ts. These interpretational techniques individually and collectively shape the attitudes of visitors to varying degrees, consequently affecting their behaviour and behavioural intentions, and thus impacting their support for conservation or satisfaction thereof.

In Figure 1, tour guiding services, visitor information, and orientation signage, and visitor codes of conduct as forms of nature interpretation are the independent variables. Visitors' attitudes are considered as the intervening variable, while visitor management objectives are the dependent variable and eventual outcomes. The premise of this research is that tour guiding services, maps, and orientation signage and visitor codes of conduct are the objects that generate and shape attitudes amongst visitors 
for support towards conservation and enhanced experience and satisfaction. On the other hand, unfavourable visitor attitudes emanating from interacting with these forms of nature interpretation will affect the realisation of visitor management objectives in nature-based tourism attractions like MMNR; that is, deviance and lack of support for conservation initiatives and poor visitor experiences and dissatisfaction. Thus, the first null hypothesis $\left({ }^{H}{ }_{0}{ }^{1}\right)$ states that nature interpretation does not influence visitors' support for conservation in MMNR. The second null hypothesis $\left({ }^{H}{ }_{0}^{2}\right)$ postulates that nature interpretation does not enhance visitors' experiences or satisfaction of MMNR.

\section{Independent Variables}

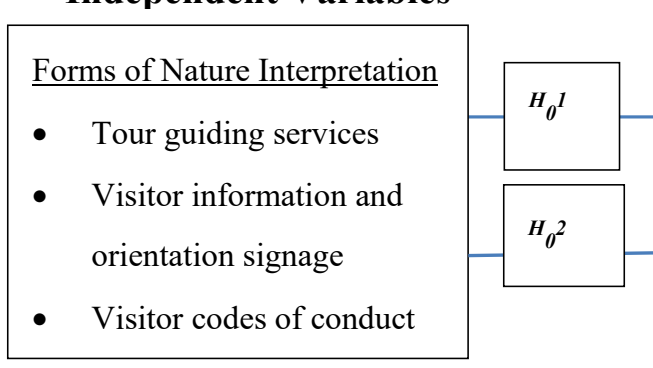

\section{Dependent Variable}

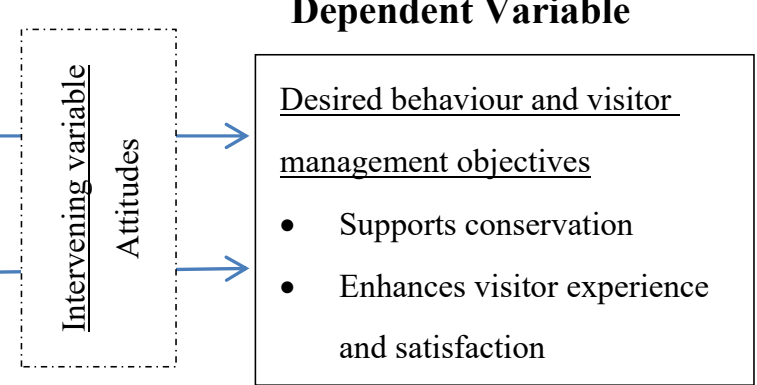

Figure 1. Conceptual Framework. KEY: ${ }^{{ }_{0}}-$ Null Hypothesis. Source: Reviewed literature and Researchers (2020).

It has been established from reviewed literature that focus has been limited to themes like relationship between nature interpretation and visitor management $[2,13,64,65]$, attitudes, or behaviour regulation $[16,19,54,66,67]$; destination management $[10,66,68,69]$, effectiveness $[23,42,70-74]$; importance $[43,45,65,74,75]$; visitor satisfaction $[65,75,76]$; and sustainability $[7,14,18,41,43,56]$. The current study not only sought to establish if nature interpretation influences the attitudes among visitors, but also the extent to which the created attitudes impact the realisation of the enhanced experience of satisfaction and support for conservation.

\section{Materials and Methods}

\subsection{Research Context}

The study was conducted in MMNR, one of the most visited reserves in Kenya. For instance, in 2018, MMNR received over 291,017 visitors, as shown in Table 1, and a total of about 62,719 safaris (tour) jeeps carrying them [77]. MMNR covers an area of $1510 \mathrm{Kms}^{2}$ and teams up with vastly diverse populations of big game; herbivores, carnivores, birdlife, and plants that breathe life over its rolling landscape. For tourists who wish to spend a night or more in MMNR, there are many accommodation facilities dotted in and around the reserve totalling over 7000 bed nights [77]. The wildlife reserve has July and August as the high season months, with June, September, October, November, and December as shoulder season months, the rest of the months are considered low season months.

Table 1. Monthly visitor arrivals into Masai Mara National Reserve (MMNR) for the period 2018-2019.

\begin{tabular}{llllllllllllll}
\hline & Jan. & Feb. & Mar. & Apr. & May & June & July & Aug. & Sept. & Oct. & Nov. & Dec. & Total \\
\hline $\mathbf{2 0 1 8}$ & 9396 & 11,870 & 12,836 & 9031 & 10,969 & 26,409 & 54,365 & 59,974 & 28,003 & 23,009 & 14,458 & 30,697 & 291,017 \\
$\mathbf{2 0 1 9}$ & 13,775 & 15,963 & 9124 & 11,190 & 7929 & & & & & & & & \\
\hline
\end{tabular}

Source: [77].

This reserve was gazetted as a national reserve in the years 1951 and situated in the County Government of Narok (C.G.N.), which manages the ecosystem, infrastructure, access permits, leases, revenue collection, and other destination management activities. The reserve lies about $265 \mathrm{Kms}$ from the city of Nairobi via Narok town that is $105 \mathrm{kms}$ away by road. There exists tarmac road to the main gate Sekenani, and this vast and remote wildlife reserve is served with a network of 
all-weather roads. Game drive trails within MMNR are preferably accessed experienced safari tour guides on four-wheel-drive vehicles. In this exciting ecosystem, visitors require nature interpretation and wilderness navigation from experienced driver guides to get an enriching experience. Besides, given the distance, MMNR, as a rich biodiversity-ecosystem, promises unforgettable experiences. Many visitors to the MMNR are rarely day trippers but overnight that averages two to three days.

\subsection{Research Design and Methods}

The research adopted a descriptive research design using a survey and semi-structured questionnaires to collect mainly quantitative data from visitors to the MMNR as respondents. The study used visitors into MMNR as a transient population with a monthly average of 11376 guests which gave a total of 22752 visitors as the study population. Data collection was from late January to mid-March 2020. These months were considered, given the relaxed atmosphere for the adequate provision and access to various nature interpretation techniques, unlike the crowded frenzy associated with high tourism seasons in the MMNR. The sample size of 351 respondents was considered the necessary minimum and thus representative of infinite populations at a $95 \%$ confidence level and a $5 \%$ confidence interval to enable the generalisation of findings. The study used a semi-structured questionnaire consisting of mainly closed-ended items rooted on Likert scale items. This choice was informed by the fact that, although attitudes are reasons for individuals behaviour, they are latent constructs that cannot be observed directly but are inferred from overt responses using Likert scale items rather than being measured directly [66-76,78]. Secondly, time and cost constraints compelled the use of questionnaires to establish the perceptions and attitudes that nature interpretation had created amongst tourists to support conservation and enhanced experience and satisfaction within a short time frame compared to the observation method.

Questionnaires for the study were distributed to visitors through their tour driver guides at the Sekenani main entry gate for filling at their convenient time. Receptionists at tourist lodges were enlisted to recruit their guests as respondents for the study during check-in or check-out. The research considered this procedure as the most practical and courteous approach for data collection, given that tourists accessed this remote destination after a long and tiring journey on safari jeeps. The filled questionnaires were dropped at the designated reception areas of the wilderness lodges, and at the exit gates by the tourist vehicle drivers. Quantitative data collected was collated and analysed using SPSS 25 software for descriptive and inferential statistics to answer research objectives. The study variables were subjected to the Pearsons's goodness-of-fit chi-square test to evaluate how well a proposed model fits or predicts research data set. This test is said to give valid results under four assumptions that is, the variables are categorical; the observations are independent; the categorical variables must be mutually exclusive, and lastly that the sample is large enough but generates less than five counts per category of grouped data. These are conditions that the data collected and collated for the current study met. Consequently, a spearman ranked order correlation test was used to establish the strength of the relationship between the attitudes created by nature interpretation versus visitors support of conservation and enhanced visitor experiences at MMNR. This correlation was used to test the hypothesis because the questionnaire predominantly had ordinal data. On the other hand, content analysis in NVIVO (version 12) was used to analyse the qualitative data from open-ended questionnaire items to establish themes. Eventually, the research employed tables and charts to present study findings.

\section{Results}

\subsection{Demographics of the Respondents}

The study had a sample ( $n$ ) size of 351 respondents, which accounted for a $54.8 \%$ response rate after administering 640 questionnaires in total for the survey, a shortfall necessitated by the challenges associated with the COVID-19 pandemic. Out of 351 respondents, $49.9 \%$ were non-residents, $32 \%$ were 
Kenyan citizens, while a further $18.1 \%$ were foreigners residending in Kenya. Concerning the gender composition of the respondents $(n=351), 54.6 \%$ were females, $44.7 \%$ males, while another $0.6 \%$ never indicated their gender. This result is indicative that there are more about $10 \%$ more males visiting MMNR that females, a statistic that implies men seek exciting wildlife tourism destinations more than females. This is against the fact that in most human adult populations, the ratio of males to females is nearly 1 , with negligible variations [62]. On the age structure of the respondents, $49.6 \%$ constituted those aged below 25 years, 39.2\% aged between 26 to 50 years, and another $11.2 \%$ aged 51 years and above. This result shows that MMNR receives more youthful tourists with over $88.8 \%(49.6 \%+39.2 \%)$ aged below 50 years and a small fraction of those above 51 years. This result could be attributed to the fact that MMNR challenging destination and has uncomfortable all-weather access roads traits that are prime considerations for senior citizens' travel decisions. As regards the educational levels of the respondents for the study; $57.6 \%$ had college-level education, $35.5 \%$ University, $5 \%$ secondary. This statistic is descriptive of an educated sample population that could adequately respond to the study.

As regards the primary purposes of visiting MMNR, in a multiple-response questionnaire item, the study established that holiday or nature-based activities $(67 \%)$ were the primary purposes of visit MMNR; this was followed by education and research (33\%) as indicated in Table 2 below. Business and work were last at $10.8 \%$ of the respondents.

Table 2. Main Purpose of Visiting MMNR (multiple responses where $n=351$ ) [79].

\begin{tabular}{ccccc}
\hline No. & Purpose of Visiting & Frequency & Per Cent & Valid Percent \\
\hline a & Business and work & 38 & 10.8 & 10.9 \\
b & Holiday and Nature-based activities & 235 & 67.0 & 67.0 \\
c & Education and Research & 116 & 33.0 & 33.1 \\
d & Others & 6 & 1.7 & 1.7 \\
& Missing values & 1 & 0.3 & \\
\hline
\end{tabular}

\subsection{Visitor Attitudes Towards Forms of Nature Interpretation in the MMNR}

The study delved into finding out the various forms of nature interpretation found in MMNR by the visiting public.

From Figure 2, 93\% of respondents indicated that tour guides in MMNR are knowledgeable as represented by strongly agree (56\%) and agree (37\%). Neither agree or disagree followed at $(4 \%)$, and last was disagree, and strongly disagree with $1 \%$ each, a further $2 \%$ was representing missing values. On the questionnaire item as to whether tour guides in MMNR were presentable, a modest $81 \%$ had positive attitudes expressed by strongly agree (34\%) and agree (47\%). Neither agree nor disagree that depicted an ambivalence had $8 \%$. Negative attitudes were represented by $6 \%$ of the respondents, that is, disagree at $4 \%$, and strongly disagree with $5 \%$ and missing values of $6 \%$. 


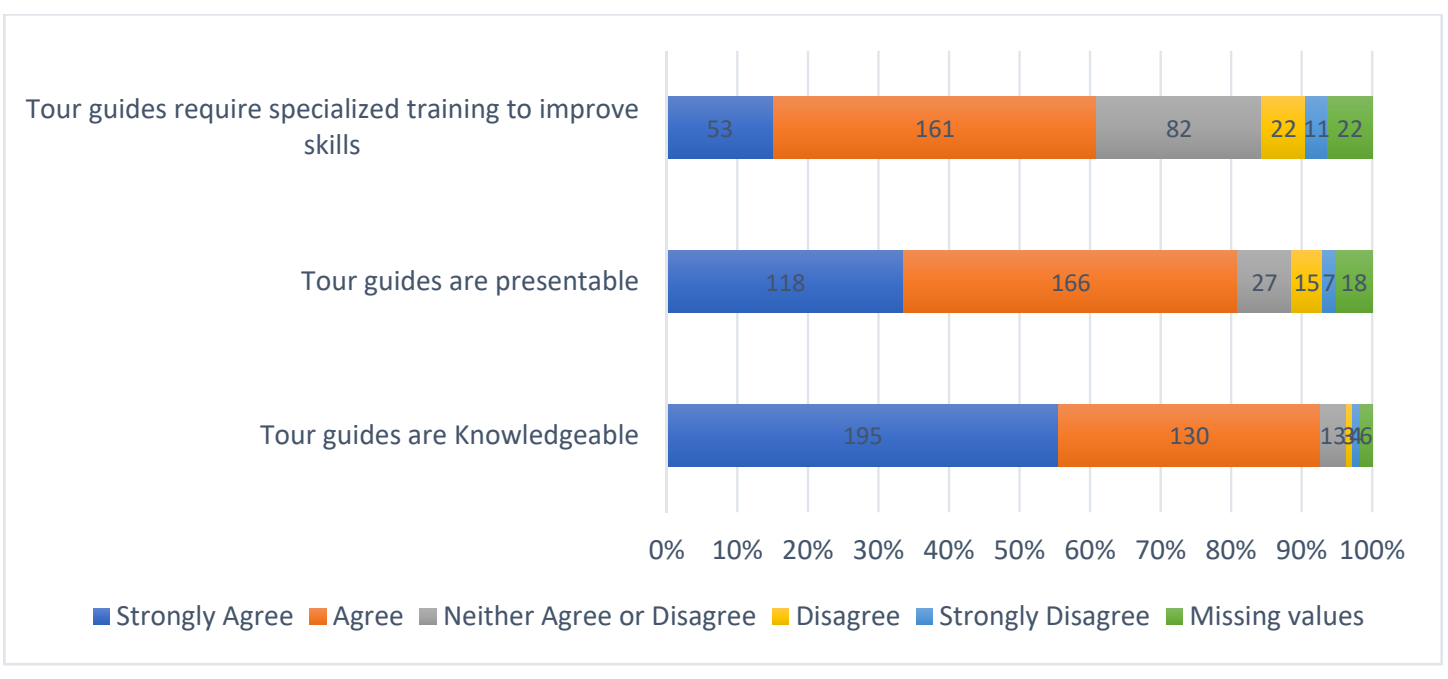

Figure 2. Showing visitors' attitudes towards tour guides in Masai Mara National Reserve (MMNR) $(n=351)$ [79].

Study results revealed that $78.1 \%$ of the respondents recognised the availability of tour guiding services in the MMNR, as detailed in Table 3. It was followed closely by visitor information and orientation signage, visitor codes $(16.2 \%)$ came at a distant third, and lastly, Others (1.7\%).

Table 3. Forms of Nature Interpretation in MMNR (where $n=351$ ) [79].

\begin{tabular}{ccccc}
\hline No. & Forms of Nature Interpretation & Frequency & Per Cent & Valid Percent \\
\hline a & Tour guiding & 274 & 78.1 & 78.1 \\
b & Visitor information and signage & 257 & 73.2 & 73.2 \\
c & Visitor codes/Do's and Don'ts & 57 & 16.2 & 16.2 \\
$\mathrm{~d}$ & Others & 6 & 1.7 & 1.7 \\
\hline
\end{tabular}

On the third attitude dummy for tour guiding, the interview sought to find out visitors' views as to whether tour guides require specialised training to improve their nature interpretation skills, $61 \%$ were affirmative, that is, strongly agree (15\%), and agree ( $46 \%)$. Further to these findings, $23 \%$ of the respondents showed ambivalence (neither agree nor disagree) to this questionnaire attitude item. Similarly, like other attributes on tour guiding, a small portion of the respondents showed negative attitudes $(9 \%) ; 6 \%$ disagreed and another 3\% strongly disagreeing that tour guides' need further training to enhance their nature interpretation skills.

Study results in Figure 3 explicitly show that the respondents had positive attitudes towards visitor information and signage. The questionnaire item, visitor signage are easy to understand and follow had the highest positive responses; $86 \%$ of the respondents responded affirmatively; $54 \%$ agree, and $32 \%$ strongly agree. Those with negative attitudes were few comprising a small aggregate total of $4 \% ; 3 \%$ disagree, and $1 \%$ strongly disagree. $7 \%$ of the respondents neither agreed nor disagreed with the statement and a further $2 \%$ missing as missing values.

Responses on visitor information and signage are adequate to meet user needs came second, with over $72 \%$ positive responses and these attitudes; $51 \%$ agree, and $21 \%$ strongly agree (Figure 3 above). In this category of questions on Visitor information and signage, this questionnaire item had relatively higher negative responses totalling 15\%; 10\% disagree, and 5\% strongly disagree. Ambivalence and missing values recorded $8 \%$ and $5 \%$, respectively. Last in this set of questions was whether reserve users followed visitor information and signage, slightly more than half of the respondents (52\%) showed positive attitudes; $38 \%$ agreed, and another $14 \%$ agreed strongly. In this set of questionnaire items, "visitor signage is followed by reserve users" had the highest ambivalence $(35 \%)$ and missing values (6\%) (Figure 3 ). 


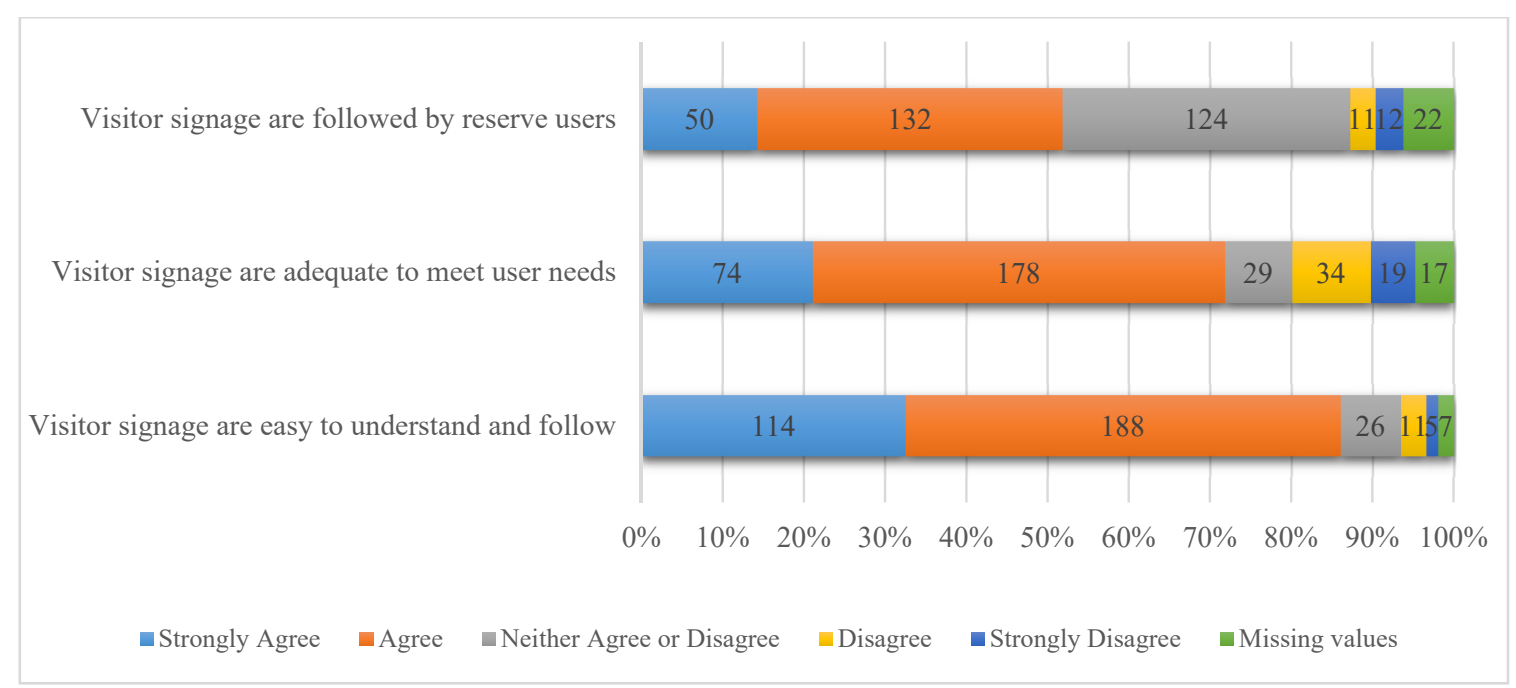

Figure 3. Attitudes towards visitor information and signage in MMNR $(n=351)$ [79].

The last set of questionnaire items used to measure attitudes towards forms of nature interpretation in MMNR was on visitor codes or rules and regulations. Similar to other types of nature interpretation, visitor codes in MMNR received affirmative responses indicating positive attitudes (Figure 4). Visitor codes are easy to understand and follow received on aggregate the highest positive responses $(89 \%)$, where $50 \%$ strongly agreed, and $39 \%$ agreed with the statement.

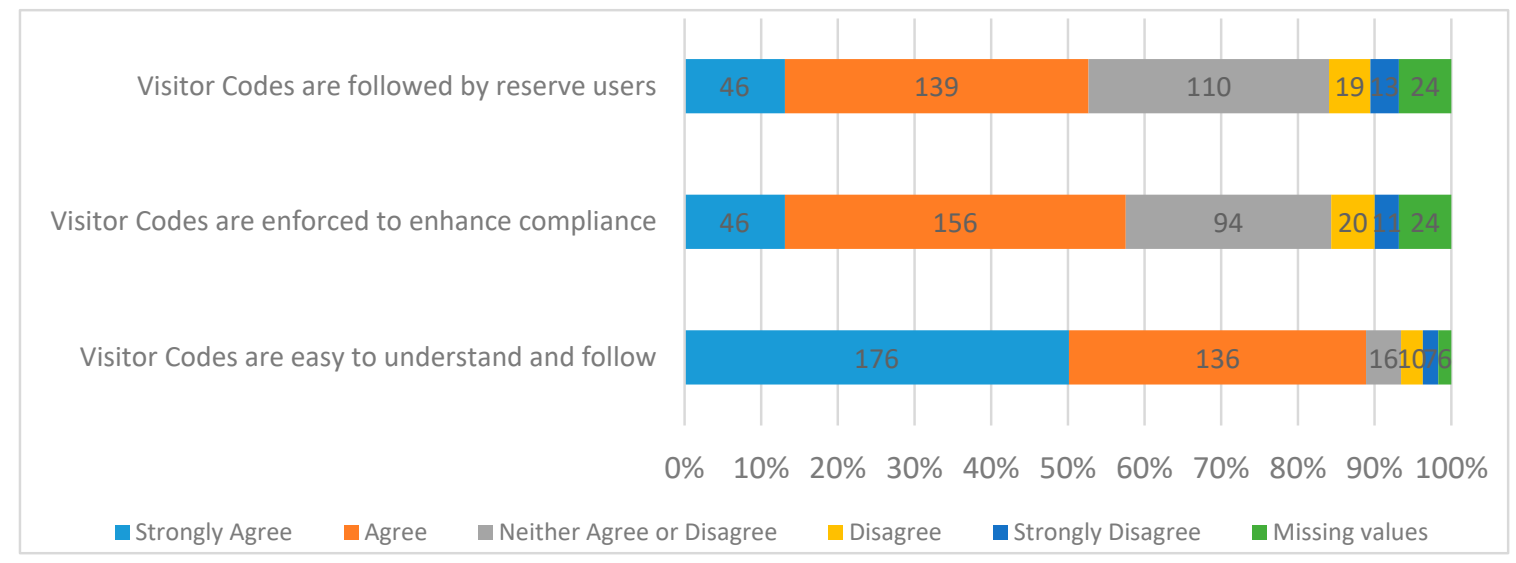

Figure 4. Attitudes towards visitor codes/do's and don'ts in MMNR $(n=351)$ [79].

Only $5 \%$ of the total respondents had negative reactions to the statement, where $3 \%$ disagreed, and a further $2 \%$ strongly disagreed. Ambivalence and missing values accounted for $2 \%$ of the respondents each. Visitor codes are enforced to enhance compliance received the second-highest positive feedback from $57 \%$ of the respondents, where $44 \%$ agreed, and $13 \%$ strongly agreed. Negative responses accounted for $9 \%$ of the answers, with $6 \%$ of the visitors disagreeing, and a further $3 \%$ on strongly disagree (Figure 4).

Interestingly, ambivalence was relatively high as $27 \%$, while missing cases accounted for $7 \%$ of the responses. "Visitor codes were observed/followed by reserve users" had an aggregate positive score of $53 \%$, where $40 \%$ agreed with the statement and a further $13 \%$ who strongly agreed with the statement. An ambivalence of 31\% was relatively higher compared to other attitudinal questionnaire items on visitor codes. Negative responses in total stood at $9 \%$, where $5 \%$ disagreed, and $4 \%$ strongly disagreed (Figure 4). Missing values accounted for $7 \%$ of the total number of respondents. 


\subsection{Attitudes Created by Nature Interpretation versus Visitor Management Objectives}

The research sought to establish the effects of NI on the support for conservation in MMNR. In this vein, the study identified three dummy variables to test visitor attitudes; these were reduced negative visitor impacts, responsible visitor behaviour, and visitors' financial support towards conservation initiatives.

Overall, there was positive visitor feedback that nature interpretation indeed supports conservation objectives in the MMNR (Figure 5 above). First, $74 \%$ of the respondents gave positive responses that Nnature interpretation leads to reduced negative visitor impacts in MMNR, represented by $44 \%$ of the respondents who strongly agreed, and another 30\% who agreed, as shown in Figure 5 below. Contrary to these attitudes amongst the majority, $17 \%$ showered negative attitudes presented by $13 \%$ who disagreed with the statement that nature interpretation leads to reduced negative visitor impacts in MMNR, and a further $4 \%$ who strongly disagreed. A small fraction of the respondents showed ambivalence $(6 \%)$ and that there were a few who never responded (3\% of missing values).

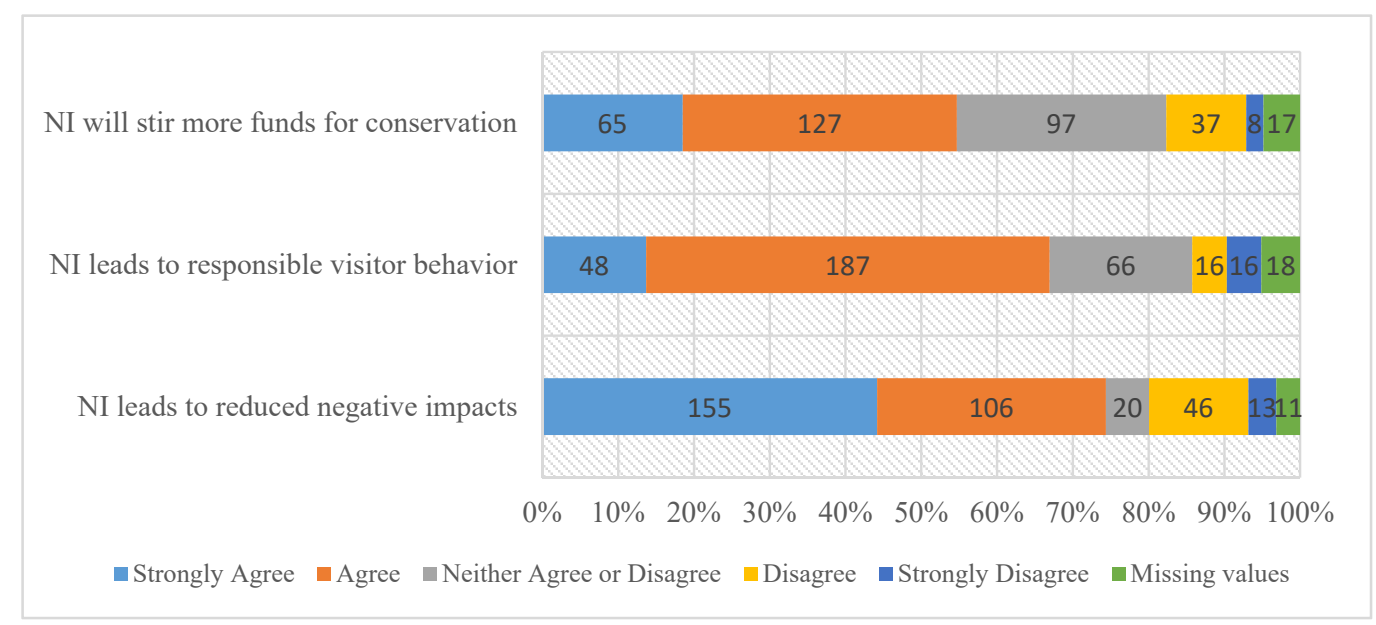

Figure 5. Nature Interpretation and support to conservation in MMNR $(n=351)$ [79].

As to whether nature interpretation provided in MMNR lead to responsible visitor behaviour, $67 \%$ of the respondents responded favourably, where $14 \%$ strongly agreed, and another $53 \%$ agreed (Figure 5). 10\% of the respondents did not agree with the notion that nature interpretation leads to responsible visitor behaviour in MMNR. A negative answer that was denoted by those who disagreed $(5 \%)$ and strongly disagreed (5\%). $19 \%$ of the respondents neither agreed nor disagreed, indicating a stance of indecisiveness, whereas a further $5 \%$ were missing values.

In an attempt to establish if the nature interpretation provided in the MMNR helped to stir people towards financially support conservation, study findings confirmed that $55 \%$ of the respondents gave an affirmative response (Figure 6 below). It was explicitly shown by the 19\% who strongly agreed to the statement that nature interpretation stirs more funds for conservation and another $36 \%$ who agreed. This questionnaire item had the highest level of ambivalence, where $28 \%$ of the respondents neither agreed nor disagreed with the statement, with a further $5 \%$ appearing as missing values. On the flip side, a total of $13 \%$ of the respondents disagreed $(11 \%)$ and strongly disagreed $(2 \%)$ with the statement that nature interpretation stirs more funds for conservation. 


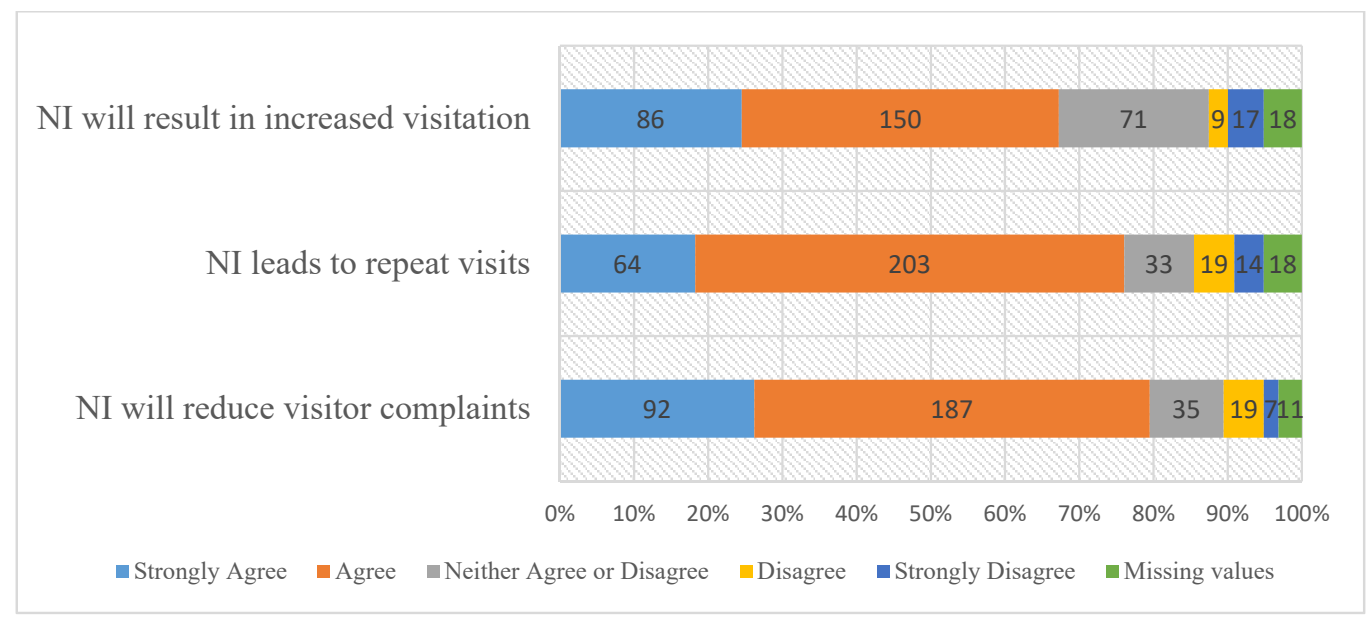

Figure 6. Nature Interpretation and visitor satisfaction in MMNR $(n=351)$ [79].

Study results show that $78 \%$ of the respondents affirmed that nature interpretation created attitudes that would reduce visitor complaints in MMNR, this was represented by $26 \%$ strongly agree, and $53 \%$ agree in Figure 6 below. Only a small fraction (7\%) of the respondents had contrary views, as represented by those who disagreed (5\%), and strongly disagreed $(2 \%)$ that nature interpretation would reduce visitor complaints in MMNR. 10\% of the respondents were uncertain, and thus neither agreed nor disagreed, while a further $3 \%$ were missing values.

Second, in the positive attitudes was the questionnaire item that nature interpretation leads to repeat visits in MMNR with an aggregate of $76 \%$ of the respondents giving their affirmation as represented by $18 \%$ who strongly agreed, and $58 \%$ who agreed in Figure 6 above. Nevertheless, $9 \%$ of the respondents either did not agree or disagree with the assertion, thereby reflecting ambivalence with another 5 percent of missed values. On the flip side, negative responses accounted for a total of $9 \%$, that is, disagree (5\%) and strongly disagree (4\%). On the questionnaire item as to whether nature interpretation provided in MMNR will lead to visitor satisfaction, a total of $68 \%$ responses were affirmative as represented by strongly agree (25\%), and agree (43\%) in Figure 6 above. Neither agree nor disagree accounted for $20 \%$, disagree $3 \%$, and strongly disagreed and missing values accounted for $5 \%$ each.

Further analysis of qualitative responses to open-ended questionnaire items on suggested measures that can be used to improve nature interpretation in MMNR, Nvivo 12 results indicated that over $87 \%$ of the responses gave positive comments, as represented by very positive (50\%), and moderately positive $(37 \%)$, with only $13 \%$ somewhat negative responses (Figure 7 below). These results generally denoted healthy positive attitudes formed as a result of nature interpretation with tour guides, signage, and display boards are facilitators.

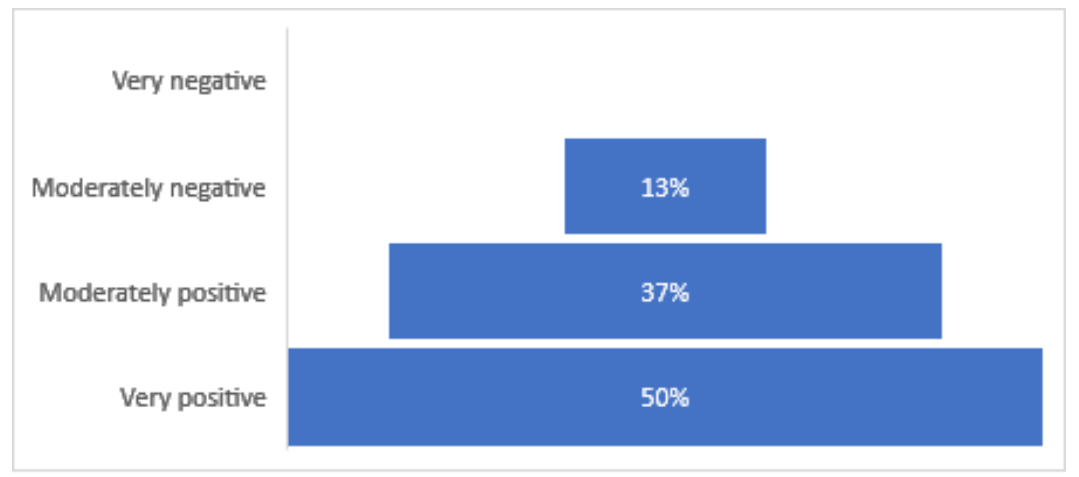

Figure 7. Summary of attitudes from qualitative data $(n=351)$ [79]. 
On further scrutiny of the qualitative data collected, seven main themes emerged; tour guides, interpretation, nature, education, research, skilled and knowledge, as detailed in Figure 8 below. Whereas tour guiding (17 counts) is a form of nature interpretation, results indicated that it plays a central role in shaping visitor attitudes and behaviour at MMNR. Interpretation (11) came second followed closely by nature (10), education came a distant fourth (5), followed by research, skilled, and knowledge that all had a count of four.

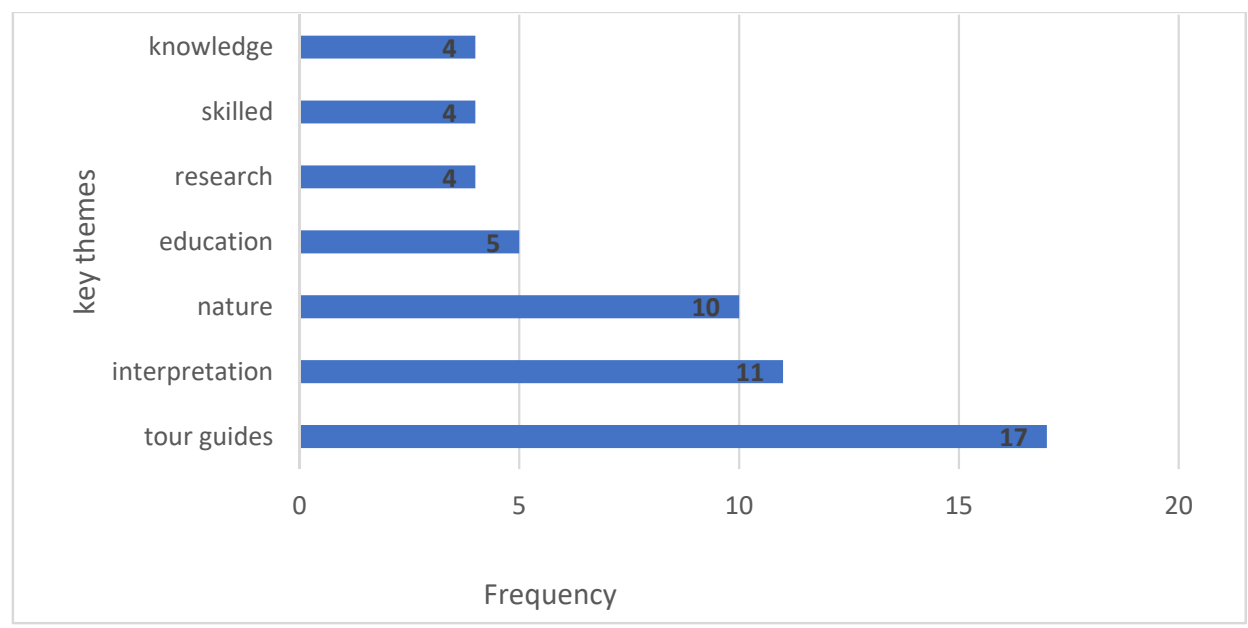

Figure 8. Key themes that emerged from qualitative data $(n=351)$ [79].

These results were further amplified by a frequency query of the thirty (30) most used words in the qualitative responses. This word frequency query revealed that although 'guides' had the highest weighted frequency, education had the highest word count and second-highest weighted percentage (Figure 9 below). Of the seven themes identified in Figure 8 above, five were among the top ten words with the highest count. These are education (1st) with 34 counts, followed by guides (2nd) with 30 counts, and nature (5th) with 17 counts, interpretation (7th) with 13 counts, and skilled (9th), with 13 counts also. The research was ranked 11th with 11 counts, and lastly, knowledge ranked 17 th with nine counts. These qualitative analysis results revealed the fact that nature interpretation is an educational activity, with eleven of the top thirty keywords relating to nature interpretation and education (Figure 9. These are education (ranked 1st), guides (2nd) nature (5th), training (6th), interpretation (7th), rules (8th), research (11th), signage (12th), knowledge (17th), languages (24th), and awareness which is ranked 25th (Figure 9).

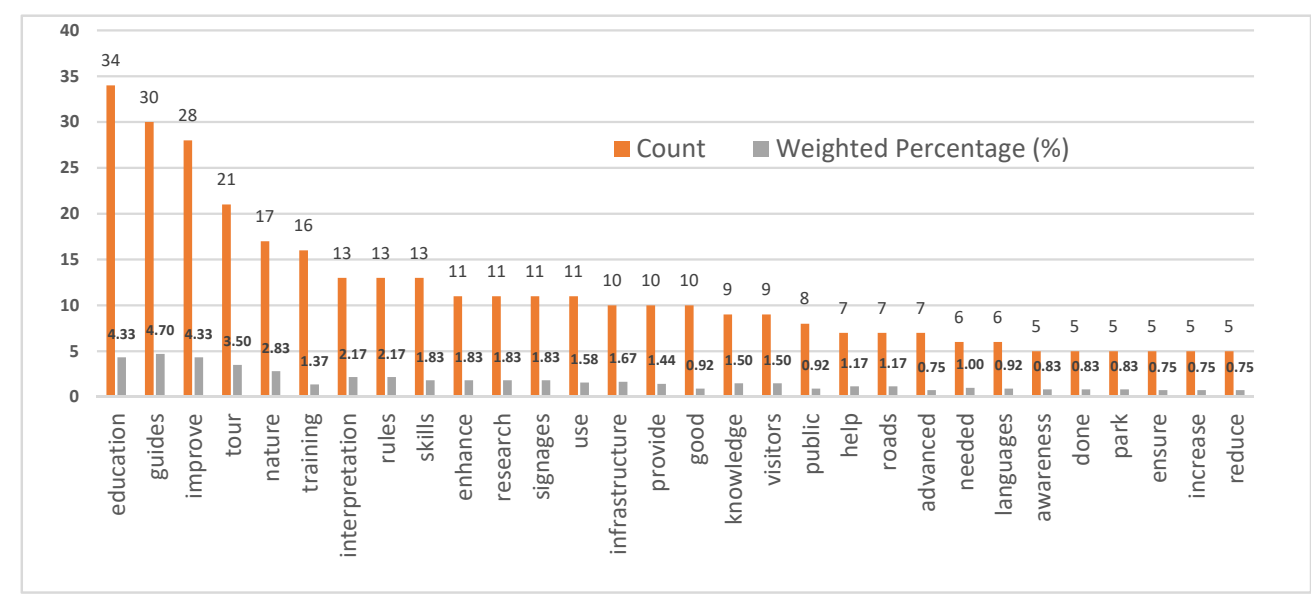

Figure 9. Counts and weighted percentages of keywords in qualitative responses [79]. 
On the other hand, verbs relating to the improvement of nature interpretation that emerged amongst the thirty keywords query are, improve (ranked 3rd), enhance (10th), provide, good, help, advanced, needed, done (26th), ensure (28th), increase (29th), and reduce (30th). These findings indeed highlighted that there is always room for continual improvement for nature interpretation to be effective in the long run. Enhanced and regular awareness creation and training of tour guides and visitor information should be programmed and executed diligently. On the other hand, visitor display boards and orientation signage requires regular maintenance and, most importantly, monitoring and evaluation.

\subsection{Hypothesis testing}

The study sought to establish if visitor attitudes formed on forms of nature interpretation will affect support for conservation in MMNR, Kenya. Using Spearman correlation, as shown in Table 4 below, research findings indicated that there is a moderate relationship between the two variables. Attitudes created by nature interpretation moderately affected support to conservation with $r_{S}=0.426$ and $p=0.000$. The calculated significance level is lower the given $p$-value of 0.05 , meaning the results are reliable up to a confidence level of $99 \%$ and an error margin of less than $1 \%$. In this regard, the null hypothesis ${ }^{H_{0}}{ }^{1}$ was rejected, and the alternate hypothesis was accepted.

Table 4. Attitudes created by nature interpretation and support for conservation $(n=351)$ [79].

\begin{tabular}{|c|c|c|c|c|c|}
\hline & & Value & Asymptotic Standard Error a & Approx. $\mathrm{T}^{\mathrm{b}}$ & Approx. Sig. \\
\hline Nominal by Nominal & Cramer's V & 0.418 & \multirow{3}{*}{0.051} & \multirow{3}{*}{8.776} & 0.000 \\
\hline Ordinal by Ordinal & Spearman Correlation & 0.426 & & & $0.000^{c}$ \\
\hline $\mathrm{N}$ of $\mathrm{Va}$ & lid Cases & 349 & & & \\
\hline
\end{tabular}

${ }^{a}$ Not assuming the null hypothesis. ${ }^{b}$ Using the asymptotic standard error assuming the null hypothesis. ${ }^{\mathrm{c}}$ Based on normal approximation.

The research subjected the null hypothesis variables to a Pearson's goodness-of-fit chi-square test. The test was intended to establish if the proposed correlation model fits into and predicts the data sets in the study. Research findings on attitudes created by nature interpretation versus support for conservation $\left({ }^{H}{ }_{0}{ }^{1}\right)$ established a $\chi^{2}(440, n=351)=1685.65$, and a calculated $p$ value of 0.000 that is lower that the given $p=05$ (Table 5 below). This were significant results that indicated the categorised likert scale data was reliable to answer the null hypothesis.

Table 5. Pearson's chi-square goodness-of-fit test $(n=351)$ [79].

\begin{tabular}{|c|c|c|c|}
\hline & Pearson Chi-Square & df & Sig. \\
\hline Attitudes on nature interpretation versus support for conservation & 1685.65 & 440 & 0.000 \\
\hline $\begin{array}{l}\text { Attitudes on nature interpretation versus enhanced } \\
\text { visitor experience and satisfaction }\end{array}$ & 607.77 & 440 & 0.000 \\
\hline
\end{tabular}

On the ${ }^{H_{0}}{ }^{2}$, attitudes created by forms of nature interpretation moderately affected visitor satisfaction $r s=0.478$ and $p=0.000$, as emphasised by Cramer's V values (Table 6 below). The calculated $p$-value was far below the given $p$-value of 0.05 . Consequently, the calculated results are reliable, up to $99 \%$ with an error margin of less than $1 \%$. In this regard, the null hypothesis $\mathrm{H}_{0} 2$ was rejected, and thus the research adopted the alternate hypothesis that there is a relationship between attitudes created by nature interpretation and visitor satisfaction. 
Table 6. Attitudes created by nature interpretation and visitor satisfaction $(n=351)$ [79].

\begin{tabular}{|c|c|c|c|c|c|}
\hline & & Value & Asymptotic Standard Error ${ }^{a}$ & Approx. $\mathrm{T}^{\mathrm{b}}$ & Approx. Sig. \\
\hline Nominal by Nominal & Cramer's V & 0.484 & & & 0.000 \\
\hline Ordinal by Ordinal & Spearman Correlation & 0.478 & 0.047 & 10.116 & $0.000^{c}$ \\
\hline \multicolumn{2}{|c|}{$\mathrm{N}$ of Valid Cases } & 348 & & & \\
\hline
\end{tabular}

${ }^{a}$ Not assuming the null hypothesis. ${ }^{\mathrm{b}}$ Using the asymptotic standard error assuming the null hypothesis. ${ }^{\mathrm{c}}$ Based on normal approximation.

A further goodness-of-fit test on the categorical data for ${ }^{H}{ }_{0}^{2}$ generated $\chi^{2}(440, n=351)=607.77$, and a calculated $p$ value of 0.000 . The calculated $p$-value of 0.000 was significantly lower that the given $p$-value of 0.05 for the current research (Table 5 above). This means the data collected was reliable to answer the null hypothesis.

\section{Discussion and Conclusions}

Study results indicate that for the low season period of January to March, MMNR is visited mainly by persons aged below 50 years $(88.8 \%)$. The respondents were $94.1 \%$ of the visitors into the MMNR had college and above level of education. This result echoes the theory that an increased level of education, means that awareness and travel propensity levels will tend to be higher (Meng \& Uysal [78]; Schmid et al. [80]). As regards the primary purposes of visiting MMNR over two-thirds of the respondents $(67 \%)$ recognised MMNR as a nature-based tourism destination. Indeed this echoes the appropriateness of the study in space and time as emphasised by UNWTO ([3,81]). This could be attributed to the fact that MMNR is a vibrant biodiversity hot spot, which has been voted five years in a row as one of the leading wildlife tourism destinations in Africa and indeed the globe [81,82]. On the other hand, the rich biodiversity of wildlife and the interwoven, social-cultural, and economic significance and management challenges at MMNR attracts a significant number of tourists for education and research (33\%).

Holiday and nature-based activities, and education and research constitute the two primary purposes of visiting MMNR. A small fraction of tourists visits MMNR for business and work-related reasons. This category of visitors could include conferencing guests retreating to this serene wilderness area, individuals providing outsourced goods and services to the myriad tourism and hospitality facilities in MMNR, just to name but a few. A study finding that could be attributed to the seasonal changes in visitor demographic profiles. The study was carried out between a shoulder season and the start of a low season when tourism products are substantially cheaper in terms of the effort and price tag of getting the services for education and research groups. The statistic for this visitor categorisation could significantly have been different if the study was carried out during the high season when demand and supply forces in the destination skims top cream consumers in the tourist market place $[83,84]$. These results on the purpose of visit notwithstanding, a further $10.8 \%$ accounted for those travelling for business and work. Given that the broader MMNR ecosystem has over 7000 total bed nights (C.G.N. [77]), and thus diversify their product offering to include conferencing guests, a finding that other scholars have endorsed in an attempt to manage the seasonality in nature-based tourism destinations [83]. This study finding also includes hospitality staff working in tourist facilities in and around the MMNR.

In an attempt to establish the forms of nature interpretation found in MMNR, study findings established that $78.1 \%$ of respondents recognised the availability of tour guiding. Although $78.1 \%$ was relatively high, it was however expected to be higher, given that a majority of the visitors in the MMNR were in chauffeur-driven tour jeeps. Further to this, tour guiding is among the most popular forms of nature interpretation in nature-based destinations [84-89]. The remainder of the respondents $(21.9 \%$ could be due to two reasons, first, that a small fraction of the respondents were on self-drive tours, and probably some of the respondents did not understand what the forms of nature interpretation are. Relative to other types of nature interpretation, the study explicitly established that there were little visitor codes (do's and don'ts) in MMNR. These results are indicative of the need for more visitor 
codes in MMNR and more awareness creation to the general public visiting the MMNR. It is important to note that visitor management through nature interpretation as a strategy will only be successful if diverse forms of nature interpretation are used for complementarity $[7,16,34,43]$ None of the forms of nature interpretation is a panacea, as endorsed by other scholars $[43,44,90]$.

The results above notwithstanding, a majority (93\%) of the respondents gave had positive attitudes towards nature interpretational knowledge possessed by the tour guides in MMNR. This statistic was indeed an overwhelming endorsement of earlier research carried out in a similar nature interpretation ecosystem in the state of Virginia, U.S.A [74,84]. However, on the contrary, there was a small fraction who had negative attitudes towards nature interpretational knowledge possessed by tour guides in MMNR. It was indicative that generally, the visitors had positive attitudes towards tour guiding services as a nature interpretation and visitor management strategy in MMNR. It was evident on all the attributes on tour guiding that were being tested and registered high aggregate positive scoring. First, tour guides are knowledgeable at $93 \%$, followed by 'tour guides are presentable' with $81 \%$, and lastly, 'tour guides require specialised training to improve skills' with an aggregate positive score of $61 \%$. The aggregate negative score or attitudes were low; 'tour guides are knowledgeable' at $2 \%$, 'tour guides are presentable' with $6 \%$, and lastly, tour guides require specialised training to improve skills with an aggregate positive score of $9 \%$. The visitors generally had positive attitudes towards tour guiding and therefore depicting its critical role in managing sustainable interactions of tourists with attractions and ecosystems like MMNR. This viewpoint has been underscored by similar earlier researches that emphasise the role of nature interpretation in visitor management at destination level with a bias towards tour guiding $[16,43,91]$.

As regards visitor codes, respondents had positive attitudes, that is, they are easy to understand and follow at $89 \%$ responses, followed by visitor codes are enforced to enhance compliance at $57 \%$ of the responses. Lastly, reserve users observe/follow visitor codes at $53 \%$. However, as positive responses decreased, ambivalence and missing values increased tremendously. It is apparent that, like other similar researches, visitor codes attract negative attitudes more unlike other forms of nature interpretation [92,93]. Indeed, as Sharpley [36], asserts that visitor codes as a destination management strategy are a necessary evil in a sense. That is, in as much as tourists enjoy the liberties and impulsiveness that holiday affords them to an extent, visitor management imposes some restrictions on that freedom. Such a strategy is bound to stir negative attitudes amongst its target audience.

Nevertheless, the visitors in this study opined that, generally, nature interpretation leads to reduced negative visitation impacts $(74 \%)$, nature interpretation leads to responsible visitor behaviour $(67 \%)$, and lastly, that nature interpretation positively stirs people towards funding conservation initiatives in MMNR (55\%). An observation that was seen to be lower relative to positive responses; some respondents showed ambivalence and uncertainty as to whether nature interpretation positively or negatively affects people's attitudes towards supporting conservation objectives. $19 \%$ for nature interpretation leads to responsible visitor behaviour, and $28 \%$ for nature interpretation stirs more funds for conservation.

Results from the qualitative analysis indicated that over $86.6 \%$ of the responses were positive, as represented by very positive (50\%), and moderately positive $(36.6 \%)$, with only $13.4 \%$ somewhat negative responses. Indeed, according to the farther of nature interpretation Freedman Tilden, it is evident that the chief aim of nature interpretation is not instruction but provocation [15]. The Elaborative Likelihood Model affirms that the more a persuasive communication makes people think, the better the likelihood of influencing and shaping positive attitudes and behaviour. Nature interpretation serves as a valid form of communication, and what is though-provoking is talk provoking. Thus a positive word of mouth simulates positive thoughts to support conservation and, most importantly, satisfaction.

Qualitative analysis identified seven main themes of the study, that is tour guides, interpretation, nature, education, research, skilled and knowledge. All these themes are critical in an effective nature interpretation strategy at any destination level. Indeed, for vast wildlife destinations like MMNR, the personal touch of tour guides has presented itself as a critical nature interpretation 
techniques that shape visitor attitudes and thereby their support for conservation and enhanced visitor experience and satisfaction. This result from the qualitative data analysis subordinated other forms of nature interpretation that were either grossly absent or had a lesser impact in creating memorable impressions in the minds of the tourists. It can also be argued that this result is because a majority of tourists in MMNR are always in the company of tour drivers cum guides. These notwithstanding for self-drive tourists, other non-personal forms of nature interpretation like visitor codes, interpretative display boards, orientation signage, and visitor information/education centres play an important role. They should, therefore, never be denounced as less important.

On further scrutiny using inferential statistics, to answer the first research objective and ${ }^{H}{ }_{0}^{2}$, study results indicated that there was a moderate relationship between attitudes created by nature interpretation and support for conservation. Thus, the research adopted the alternate hypothesis that there is a relationship between attitudes created by nature interpretation and support for conservation. Although, earlier investigations observed that nature interpretation influences visitors attitudes that consequently lead them to support the conservation of attractions $[16,20,23,24,43]$, findings of this study have endorsed this notion with some caution. The current research observes that this relationship highly depends on how nature interpretation is implemented. Current study findings have established a moderate correlation between the attitudes created by nature interpretation and the support for conservation as a visitor management strategy. These results suggest that, if nature interpretation were uniformly, consistently, and diligently delivered by all stakeholders, it would have had a higher impact on shaping visitor attitudes and thereby the resultant behaviour and behaviour intentions. On the flip side, it will not have a meaningful effect if the implementation of nature interpretation lacks uniformity, consistency, and commitment by all its stakeholders.

On the second objective and ${ }^{H}{ }^{2}$, study results established that there is a moderate relationship between attitudes created by nature interpretation and visitor satisfaction as inferred by spearman correlation. Indeed, further descriptive statistics confirmed these results; $78 \%$ of respondents endorsed the statement that nature interpretation reduces visitor complaints in MMNR. An additional 76\% acknowledged that nature interpretation could lead to repeat visits, and lastly, $68 \%$ affirmed that nature interpretation could lead to increased visitation in MMNR. This finding generally resonates well with other earlier researches that link nature interpretation's potential to create positive attitudes and consequently enhanced visitor experiences and visitor satisfaction $[32,42,45,83,94]$. Although the current study findings resonate with earlier studies, the present results underscore the strength of this correlation. In the case of MMNR where there exist diverse stakeholders involved in nature interpretation with different visitor management objectives, the moderate relationship exists in an environment that lacks uniformity, consistency, and diligence by all interested parties. These include the management of MMNR as the provider and regulator of nature interpretation, the tourist lodges, tour operators, tour guides as providers and consumers, and lastly, the tourists as the consumers of nature interpretation. In this regard, the current study results suggested that nature interpretation would have had a higher impact on shaping visitor attitudes and thereby enhanced visitor experience and satisfaction if uniformly, consistently, and diligently delivered by all the relevant stakeholders.

This finding presents a complex visitor management scenario and therefore calls for interpreted and coordinated stakeholder efforts and programmes. Whereas the CGN and the management of MMNR might be keen on balancing between conservation and visitor satisfaction by creating a favourable nature interpretation environment, other stakeholders should be involved to share the common vision for the sustainability of the destination area. The focus should not only be on designing and enforcing visitor codes and other interpretative initiatives but also awareness creation programmes and importantly monitoring and evaluation to ensure their effectiveness $[69,74,94-96]$. The development and proper sighting of orientation signage and display boards should be accompanied by the provision of adequate road infrastructure, wildlife viewing trails and designated viewing points. This is because it has been observed that inadequate, poor or impassable roads necessitate most off-road or off-trail driving in wildlife destinations [97-99]. The development of visitor information centres at 
designated areas and entry points will go along way to enhance, nature interpretative experiences for those visiting MMNR. Visitor information centres at main entry points will not only provide a sneak preview of what to expect at the destination but also reminding visitors of the code of conduct. Most tourists briefly stop at the entry or exit points as they check-in, check-out or even a little stretch up after long hours in the tour vehicles. The visitor information centres will supplement other existing amenities like cloakrooms, customer care services but also double up as attractions in themselves.

Among other things, study results underscore the role of nature interpretation in visitor management at attraction and level and should always be part of the tourist destination manager's planning and implementation tool kit. Although the study was carried out in low season when the visitor demographics might be different as well as the travel motives and behaviour, it is imperative to note that nature interpretation is indispensable and never changes. This implies that there might be more monitoring and evaluation, more often repositioning of temporary display boards and orientation signage, and deployment more tour guides and awareness programmes, in the high season compared to a low season. And therefore, the only variable that that might change is the level of resource commitment towards nature interpretation from one season to another.

Therefore, the research concludes that various forms of nature interpretation result in the formation of attitudes that consequently moderately affect the realisation of visitor management objectives in MMNR; that is, support for conservation and visitor satisfaction. Study results attest that nature interpretation, among other phenomena not included in the study, affects the realisation of visitor management objectives. However, unlike other study findings, the current study sought to establish the extent to which nature interpretations shape attitudes towards support for conservation and enhanced visitor experience or satisfaction. Tour guiding created healthier positive attitudes that enhanced visitor experience and visitor satisfaction and could elicit support for conservation. Other non-personal forms of nature interpretation like display boards, visitor codes, and orientation signage created moderate attitudes. These notwithstanding, the non-personal forms of nature interpretation play a complementary role and served as critical infrastructure for individual tourists on self-drive tours. The low season months appears to attract a significant number of youthful tourists.

The study recommends diligent monitoring and evaluation and other continuous improvement initiatives to be instituted to unlock the full potential of nature interpretation as a visitor management strategy. The study further recommends the development of visitor education or information centres that are strategically situated within the expansive MMNR. Interpretational training for tour guides, regular environmental education, and awareness creation on the code of conduct combined with a consistent, well-coordinated, and meticulous implementation of nature interpretation initiatives by all stakeholders in MMNR would sustain a cumulative and long-term impact of this visitor management strategy. This study was carried out during low season months, thus calling for follow-up research to be carried out during the high season months when the MMNR is abuzz with touristic activities; a period when tourist facilities and resources are stretched to the extreme to establish if there is any variance from the current study findings.

Author Contributions: Conceptualisation, L.O.J., I.M.B. and A.K.-V.; methodology, L.O.J., I.M.B. and A.K.-V.; software, L.O.J. and I.B.M.; validation, L.O.J. and A.K.-V.; formal analysis, L.O.J. and A.K.-V.; investigation, L.O.J., I.B.M. and A.K.-V.; resources, L.O.J. and A.K.-V.; data curation, L.O.J. and I.B.M.; writing-original draft preparation, L.O.J.; writing-review and editing, L.O.J., I.B.M. and A.K.-V.; visualisation, L.O.J.; supervision. All authors have read and agreed to the published version of the manuscript.

Funding: This research received no external funding.

Acknowledgments: First and foremost, we would like to acknowledge the administrative support received from the Faculty of Economics and Social Sciences of Szent Istvan University, Hungary. We also acknowledge the staff and management of C.G.N. and MMNR for allowing the research to be carried out in one of Kenya's premium game reserves. The tourism officers managing the Sekenani gate of MMNR, the game rangers, tour guides, lodge managers, and receptionists who, in their various roles, assisted in circulating the questionnaires to the tourists for the survey.

Conflicts of Interest: The authors declare no conflict of interest. 


\section{References}

1. Eagles, P.F.J.; Coburn, J.; Swartman, B. Plan quality and plan detail of visitor and tourism policies in Ontario Provincial Park management plans. J. Outd. Recreat. Tour. 2014, 7-8, 44-54. [CrossRef]

2. Raasch, U. Interpretation as a Visitor Management Strategy in National Parks; A Case Study of Jasmund National Park on the Island of Rügen, Germany; Bournemouth University: London, UK, 2004.

3. UNWTO. Continued Healthy Growth in International Tourism in the First Nine Months of 2018; World Tourism Barometer: UNWTO: Madrid, Spain, 2018.

4. UNWTO. Tourism in Africa: A Tool for Development. UNWTO, Affiliate Members Regional Report, 4 (Tourism in Africa: A Tool for Development; UNWTO: Madrid, Spain, 2015.

5. Pearce, D.G.; Schänzel, H.A. Destination management: The tourists' perspective. J. Destin. Market. Manag. 2013, 2, 137-145. [CrossRef]

6. Bushell, R.; Bricker, K. Tourism in protected areas: Developing meaningful standards. Tour. Hosp. Resefarch 2017, 17, 106-120. [CrossRef]

7. Leung, Y.; Spenceley, A.; Hvenegaard, G.; Buckley, R.; Groves, C. Tourism and Visitor Management in Protected Areas: Guidelines for Sustainability; IUCN: Gland, Switzerland, 2018. [CrossRef]

8. Zelenka, J.; Kacetl, J. Visitor management in protected areas. Czech J. Tour. 2013, 2, 5-18. [CrossRef]

9. Kebete, Y.; Wondirad, A. Visitor management and sustainable destination management nexus in Zegie Peninsula, Northern Ethiopia. J. Destin. Market. Manag. 2019, 13, 83-98. [CrossRef]

10. Olson, E.C.; Bowman, M.L.; Roth, R.E. Interpretation and Nonformal Environmental Education in Natural Resources Management. J. Environ. Educ. 1984, 15, 6-10. [CrossRef]

11. McArthur, S.; Hall, C. Visitor management: Principles and practice. Heritage Management in New Zealand and Australia; McArthur, S., Hall, C., Eds.; Oxford University Press: London, UK, 1996; pp. 37-51.

12. Van der Donk, M. Framework for a Visitor Management Plan. Visitor Management P.A.N. Parks. 2014. Available online: http://www.panparks.org/sites/default/files/docs/publications-resources/asnatureintended_ large_0.pdf (accessed on 18 May 2020).

13. Albrecht, J.N. Introduction to Visitor Management in Tourism Destinations. In Visitor Management in Tourism Destinations; Albrecht, J.N., Ed.; CABI: Wallingford, UK, 2017; pp. 3-8. [CrossRef]

14. Candrea, A.N.; Ispas, A. Visitor Management, a Tool for Sustainable Tourism Development in Protected Areas. Bull. Transilv. Univ. Brasov. Ser. V Econ. Sci. 2009, 2, 131-136.

15. Tilden, F. Interpreting our heritage. In Chapel Hill Books; University of North Carolina Press: Chapel Hill, NC, USA, 1997; Available online: https://doi.org/973.07TIL (accessed on 23 November 2019).

16. Juma, L.O. Nature Interpretation and Visitor Management in Protected Areas: An Analysis of Stakeholder Attitudes; Lambert Academic Publishing: Saarbrücken, Germany, 2016.

17. Ham, S.H.; Sandberg, E.K. Interpretation as Strategic Communication in Protected Area Management. In The 6th International Conference on Monitoring and Management of Visitors in Recreational and Protected Areas, Stockholm, Sweden, 21-24 August 2012; Fredman, P., Stenseke, M., Liljedahl, H., Mossing, A., Daniel, L., Eds.; MMV: Stockholm, Sweden, 2012; pp. 132-133.

18. Hovardas, T.; Togridou, A.; Pantis, J.D. Environmental education as a crucial component of the environmentalist dimension of ecotourism: Inducing short-term effects on environmental literacy with long-term implications for protected area management. In Ecotourism: Management, Development and IMPACT; Nova Science Pub Inc.: London, UK, 2011.

19. Edinborough, P.; Frew, E.A.; Hodgson, L.; Wearing, S. Enhancing Visitor Experience Through Interpretation: An Examination of Influencing Factors; CRC for Sustainable Tourism: Queensland, Australia, 2008.

20. Goh, H.C.; Rosilawati, Z. Conservation education in Kinabalu park, Malaysia: Analysis of visitors' satisfaction. J. Trop. Forest Sci. 2014, 26, 208-217.

21. Jaafar, M.; Kayat, K.; Tangit, T.M.; Yacob, M.F. Nature-based rural tourism and its economic benefits: A case study of Kinabalu National Park. Worldw. Hosp. Tour. Themes 2013. [CrossRef]

22. Zuliskandar, R. Heritage Tourism in Malaysia: Potential Challenges. Soc. Sci. 2017, 12, 431-440. [CrossRef]

23. Haring, D.S.D. Effective interpretation for recreational marine resource use in the Mombasa Marine Park and Reserve, Kenya [James Cook University, Townsville, Australia]. 2014. Available online: http: //researchonline.jcu.edu.au/40679/ (accessed on 17 September 2019). 
24. Kenya Tourist Board (K.T.B.). The Nairobi Safari Walk. 2012. Available online: http://www.magicalkenya. com/index.php?option=com_contenttask=viewid=271Itemid=415 (accessed on 17 September 2019).

25. Akama, J.; Kemboi, D. The development of cultural tourism in Kenya: A case study of the Bomas of Kenya. In Cultural Tourism in Africa: Strategies for the New Millennium; Akama, J.S., Sterry, P., Eds.; Association for Tourism and Leisure Education: Arnhem, The Netherlands, 2000; Available online: http: //www.atlas-euro.org/pages/pdf/CulturaltourisminAfricaDeel1.pdf (accessed on 17 September 2019).

26. Sitati, N.W.; Ipara, H. Indigenous Ecological Knowledge of a Human-Elephant Interaction in Transmara District, Kenya: Implications for Research and Management. Adv. Anthropol. 2012, 2, 107. [CrossRef]

27. Sterry, P. Interpreting cultural heritage: The challenge for African initiatives. In Cultural Tourism in Africa: Strategies for the New Millennium; Akama, J., Sterry, P., Eds.; Association for Tourism and Leisure Education: Arnhem, The Netherlands, 2000; pp. 184-185. Available online: http://www.atlas-euro.org/pages/pdf/ CulturaltourisminAfricaDeel1.pdf (accessed on 17 September 2019).

28. Ikiara, M.; Okech, C. Impact of Tourism on Environment in Kenya: Status and Policy. In KIPPRA Discussion Paper, 19th ed.; Kenya Institute for Public Policy Research and Analysis: Nairobi, Kenya, 2002. Available online: https://www.eldis.org/document/A21267 (accessed on 17 September 2019).

29. Adeola, A.; Aderemi Ayinla, A. Rural Tourism Entrepreneurship as Strategy for Economic Development in Nigeria. Schol. Int. J. Manag. Dev. 2016, 3, 164-175, ISSN 2394-3378. [CrossRef]

30. UNWTO. UNTWO Tourism Highlights: 2017 Editon; UNWTO: Madrid, Spain, 2017.

31. Frost, W.; Laing, J.; Beeton, S. The Future of Nature-Based Tourism in the Asia-Pacific Region. J. Travel Res. 2014, 53, 721-732. [CrossRef]

32. Chen, J.S.; Prebensen, N.K. Nature Tourism. In Nature Tourism; Chen, J.S., Prebensen, N.K., Eds.; Routledge: Abingdon, UK, 2017. [CrossRef]

33. Bayliss, J.; Schaafsma, M.; Balmford, A.; Burgess, N.D.; Green, J.M.H.; Madoffe, S.S.; Okayasu, S.; Peh, K.S.H.; Platts, P.J.; Yu, D.W. The current and future value of nature-based tourism in the Eastern Arc Mountains of Tanzania. Ecosyst. Ser. 2014, 8, 75-83. [CrossRef]

34. Buckley, R.; Zhong, L.; Ma, X. Visitors to protected areas in China. Biol. Conserv. 2017, 209, 83-88. [CrossRef]

35. Carranza, T.; Manica, A.; Kapos, V.; Balmford, A. Mismatches between conservation outcomes and management evaluation in protected areas: A case study in the Brazilian Cerrado. Biol. Conserv. 2014, 173, 10-16. [CrossRef]

36. Karanth, K.K.; DeFries, R. Nature-based tourism in Indian protected areas: New challenges for park management. Conserv. Lett. 2011, 4, 137-149. [CrossRef]

37. Lee, T.H.; Jan, F.H. Ecotourism Behavior of Nature-Based Tourists: An Integrative Framework. J. Travel Res. 2018, 57, 792-810. [CrossRef]

38. Lóczy, D.; Ciglić, R. Nature Conservation; Springer: Cham, Switherland, 2018. [CrossRef]

39. Sharpley, R. Tourism development and the environment: Beyond sustainability? In Tourism Development and the Environment: Beyond Sustainability? Routledge: London, UK, 2009. [CrossRef]

40. Sharpley, R. Travel and Tourism; SAGE Publications Ltd.: Sauzend Oaks, CA, USA, 2006. [CrossRef]

41. Bhati, A.; Pearce, P. Tourist behaviour, vandalism and stakeholder responses. In Visitor Management in Tourism Destinations; CABI: Wallingford, UK, 2017. [CrossRef]

42. Kuo, I.-L. The effectiveness of environmental interpretation at resource-Sensitive tourism destinations. Int. J. Tour. Res. 2002, 4, 87-101. [CrossRef]

43. Alazaizeh, M.; Hallo, J. Indicators and standards-based visitor management frameworks in achieving sustainability at cultural heritage sites. In Visitor Management in Tourism Destinations; CABI: Wallingford, UK, 2017. [CrossRef]

44. Bakiewicz, J.; Leask, A.; Barron, P.; Rakic, T. Using heritage interpretation to manage film-induced tourism at heritage visitor attractions. In Visitor Management in Tourism Destinations; CABI: Wallingford, UK, 2017. [CrossRef]

45. Durao, M.; Joao, C.M. Strategies for successful interpretation techniques in visitor attractions: The operationalisation of guided tourism in museums. In Visitor Management in Tourism Destinations; Albrecht, J.N., Ed.; CABI: Wallingford, UK, 2017; pp. 131-150.

46. Shackley, M. Visitor Management. In Visitor Management; Routledge: Abingdon, UK, 2009. [CrossRef]

47. Mason, P. Visitor Management in Protected Areas: From 'Hard' to 'Soft' Approaches? Curr. Issues Tour. 2005, 8, 181-194. [CrossRef] 
48. Marschall, S.; Granquist, S.M.; Burns, G.L. Interpretation in wildlife tourism: Assessing the effectiveness of signage on visitor behaviour at a seal watching site in Iceland. J. Outd. Recreat. Tour. 2017, 17, 11-19. [CrossRef]

49. Farrell, T.A.; Marion, J.L. The Protected Area Visitor Impact Management (PAVIM) Framework: A Simplified Process for Making Management Decisions. J. Sustain. Tour. 2002, 10, 31-51. [CrossRef]

50. Hall, C.M.; McArthur, S. Heritage Management in Australia and New Zealand: The Human Dimension; Oxford University Press: Auckland, New Zealand, 1996. Available online: https://catalogue.nla.gov.au/Record/ 1332915 (accessed on 16 June 2020).

51. Donk, C.S.P. Developing a Visitor Management Framework for W.W.F.'s P.A.N. Parks Project: Case Study of a National Park in France. In Monitoring and Management of Visitor Flows in Recreational Protected Areas; Arnberger, A., Brandenburg, C., Muhar, A., Eds.; MMV: Vienna, Austria, 2002.

52. Republic of Kenya. Kenya Tourism Agenda 2018-2022. 2018. Available online: http://www.tourism.go.ke/ wp-content/uploads/2018/06/Agenda-18-22-Final-4Launch.pdf (accessed on 16 June 2020).

53. Republic of Kenya. Ministry of Tourism and Wildlife. 2019. Available online: www.tourism.go.ke (accessed on 16 June 2020).

54. $\mathrm{Xu}, \mathrm{F}$; Fox, D. Modelling attitudes to nature, tourism and sustainable development in national parks: A survey of visitors in China and the UK. Tour. Manag. 2014, 45, 142-158. [CrossRef]

55. Ceballos-Lascuráin, H. Tourism, Ecotourism, and Protected Areas; IUCN: Grand, Swiss, 1996. [CrossRef]

56. Hansen, D.; Fowler, J. Protect and Present—Parks Canada and Public Archaeology in Atlantic Canada. In Past Meets Present; Jameson, J.H., Baugher, S., Eds.; Springer: New York, NY, USA, 2007. [CrossRef]

57. Borges, D.L.; Ronda, J.G. Whale and Dolphin Watching, and Visitors' Experiential Responses: A Qualitative Study on Comments in a Travel Forum. In Wildlife Tourism, Environmental Learning and Ethical Encounters; de Borges, L.I., Green, R.J., Eds.; Springer International Publishing: Cham, Switzerland, 2017; Volume 11, pp. 183-193. [CrossRef]

58. Kenya Wildlife Service. Nairobi National Park Ecosystem Management Plan (2005-2010); Kenya Wildlife Service: Nairobi, Kenya, 2005.

59. Fishbein, M.; Ajzen, I. Predicting and Changing Behavior: The Reasoned Action Approach; Psychology Press: New York, NY, USA, 2010.

60. Cacioppo, J.T.; Petty, R.E.; Kao, C.F.; Rodriguez, R. Central and peripheral routes to persuasion: An individual difference perspective. J. Personal. Soc. Psychol. 1986, 51, 1032-1043. [CrossRef]

61. Griffin, R.W. Attitude Theory. In Wiley Encyclopedia of Management; Littlejohn, S.W., Foss, K.A., Eds.; John Wiley Sons, Ltd.: Hoboken, NJ, USA, 2015; p. 1. [CrossRef]

62. Mucha, D.; Halpenny, E. Exploring the human dimension: Visitor use analysis of Park, Willmore Wilderness. In The 6th International Conference on Monitoring and Management of Visitors in Recreational and Protected Areas, Stockholm, Sweden, 21-24 August 2012; Fredman, P., Stenseke, M., Liljedahlhl, H., Mossing, A., Daniel, L., Eds.; MMV: Stockholm, Sweden, 2012; pp. 388-389.

63. Mucha, D.; Halpenny, E. Using a Mixed-Methods Approach to Explore the Human Dimension of Willmore Wilderness Park, Alberta, Canada. In The 6th International Conference on Monitoring and Management of Visitors in Recreational and Protected Areas, Stockholm, Sweden, 21-24 August 2012; Fredman, P., Stenseke, M., Liljedahlhl, H., Mossing, A., Daniel, L., Eds.; MMV: Stockholm, Sweden, 2012; pp. 271-290.

64. McGrath, G.M. Tour Guides as Interpreters of Archaeological Sites: Heritage Tourism in Cusco, Peru. In PQDT-Global; University of Surrey: Surrey, UK, 2005.

65. Weiler, B.; Walker, K. Enhancing the visitor experience: Reconceptualising the tour guide's communicative role. J. Hosp. Tour. Manag. 2014, 21, 90-99. [CrossRef]

66. Milfont, T.L.; Duckitt, J. The environmental attitudes inventory: A valid and reliable measure to assess the structure of environmental attitudes. J. Environ. Psychol. 2010, 30, 80-94. [CrossRef]

67. Papageorgiou, K. A Combined Park Management Framework Based on Regulatory and Behavioral Strategies: Use of Visitors' Knowledge to Assess Effectiveness. Environ. Manag. 2001, 28, 61-73. [CrossRef]

68. Powell, R.B.; Ham, S.H. Can ecotourism interpretation really lead to pro-conservation knowledge, attitudes and behaviour? Evidence from the Galapagos Islands. J. Sustain. Tour. 2008, 16, 467-489. [CrossRef]

69. Munro, J.K.; Morrison-Saunders, A.; Hughes, M. Environmental Interpretation Evaluation in Natural Areas. J. Ecotour. 2008, 7, 1-14. [CrossRef] 
70. Pierssené, A. Environmental interpretation. Explain. Our World 2010, 1-14. [CrossRef]

71. Coghlan, A.; Ruth Fox, K.; Prideaux, B.; Lück, M. Successful interpretation in great barrier reef tourism: Dive in or keep out of it? Tour. Mar. Environ. 2011, 7, 167-178. [CrossRef]

72. Inversini, A.; Buhalis, D.; Pesonen, J. Agile Marketing for Tourism Destinations. In Proceedings of the Academy of Marketing Conference 2014, Bournemouth, UK, 7-10 July 2014.

73. Littlefair, C.J. The Effectiveness of Interpretation in Reducing the Impacts of Visitors in National Parks; National Parks Griffith University: Queensland, Australia, 2003.

74. Sim, K.-W.; Kim, B.-G.; Lee, J.-H.; Poung-Sik, Y. The evaluation of effectiveness of the interpretive program at national parks. J. Outd. Recreat. Tour. 2018, 21, 69-75. [CrossRef]

75. Moscardo, G. Interpretation and tourism: Holy grail or emperor's robes? Int. J. Cult. Tour. Hosp. Res. 2014, 8. [CrossRef]

76. Huang, S.; Weiler, B.; Assaker, G. Effects of Interpretive Guiding Outcomes on Tourist Satisfaction and Behavioral Intention. J. Travel Res. 2015, 54, 344-358. [CrossRef]

77. County Government of Narok (C.G.N.). Masai Mara Visitation Trends 2018-2019; County Government of Narok: Narok, Kenya, 2020.

78. Crano, W.D. Attitudes and Attitude Change. In Attitudes and Attitude Change; Psychology Press: New York, NY, USA, 2011. [CrossRef]

79. Juma, L.O.; Bakos, I.M.; Khademi-Vidra, A. Research Data as Analyzed Using Data Analysis Software; SPSS, Excel, and Nvivo 12; Szent Istvan University: Godollő, Hungary, 2020.

80. Schmid, B.; Balac, M.; Axhausen, K.W. Post-Car World: Data collection methods and response behavior in a multi-stage travel survey. Transportation 2019, 46, 425-492. [CrossRef]

81. UNWTO. Tourism-Key to development, prosperity and well-being, International tourism in 2016-Key trends and outlook. In UNTWO Tourism Highlights: 2017 Editon; UNWTO: Madrid, Spain, 2017; Volume 1-2, pp. 2-4.

82. CNN. African Safari: 8 Best National Parks to View Wildlife|CNN Travel. CNN Travel. 2018. Available online: https:/edition.cnn.com/travel/article/africa-safari-national-parks/index.html (accessed on 24 August 2020).

83. World Travel Awards. Africa's Leading National Park 2018. World Travel Awards-2018. 2018. Available online: https://www.worldtravelawards.com/award-africas-leading-national-park-2018 (accessed on 24 August 2020).

84. Connell, J.; Page, S.J.; Meyer, D. Visitor attractions and events: Responding to seasonality. Tour. Manag. 2015, 46, 283-298. [CrossRef]

85. Kim, Y.; Kim, C.; Lee, D.K.; Lee, H.; Andrada, R.I.T. Quantifying nature-based tourism in protected areas in developing countries by using social big data. Tour. Manag. 2019, 72, 249-256. [CrossRef]

86. Kabii, F.; Wandaka, J.K.M.; Jilo, N. Assessment of the impact of Smartphone Technology on Tour Guide Performance in Kenya. Int. J. Soc. Sci. Res. 2019. [CrossRef]

87. Makopo, B.M.; Geldenhuys, S.; Sime, L. The role of tourist guides in interpretation: A survey of secondary school teachers at Maropeng and the Sterkfontein caves, South Africa. Afr. J. Hosp. Tour. Leisure 2018, 7, 12-25.

88. Pabel, A.; Pearce, P.L. Selecting humour in tourism settings-A guide for tourism operators. Tour. Manag. Perspect. 2018, 25, 64-70. [CrossRef]

89. Panca Syahputra, B. Study of the Interpreting Techniques used by the Tourist Guides in the Tourism Attractions of North Sumatra. Int. J. Engl. Lang. Treansl. Stud. 2017, 5, 14-20.

90. Yang, S.-Y.; Hsu, C.-L. A location-based services and Google maps-based information master system for tour guiding. Comput. Electr. Eng. 2016, 54, 87-105. [CrossRef]

91. Rodríguez-López, N.; Diéguez-Castrillón, M.I.; Gueimonde-Canto, A. Sustainability and Tourism Competitiveness in Protected Areas: State of Art and Future Lines of Research. Sustainability 2019, 11, 6296. [CrossRef]

92. Poudel, S.; Nyaupane, G.P. The Role of Interpretative Tour Guiding in Sustainable Destination Management: A Comparison between Guided and Nonguided Tourists. J. Travel Res. 2013, 52, 659-672. [CrossRef]

93. Holmes, A.P.; Grimwood, B.S.R.; King, L.J. Creating an Indigenized visitor code of conduct: The development of Denesoline self-determination for sustainable tourism. J. Sustain. Tour. 2016, 24, 1177-1193. [CrossRef]

94. Roberts, M.; Mearns, K.; Edwards, V. Evaluating the effectiveness of guided versus non-guided interpretation in the Kruger National Park, South Africa. Koedoe 2014, 56, 1-8. [CrossRef] 
95. Patroni, J.; Simpson, G.; Newsome, D. Feeding wild fish for tourism-A systematic quantitative literature review of impacts and management. Int. J. Tour. Res. 2018, 20, 286-298. [CrossRef]

96. Mayorga, M.; Cable, T.T.; Mullins, C. Evaluation of Interpretive Media Use and Effectiveness at a Nature Center. J. Interp. Res. 2017, 22, 15.

97. Mifsud, M.C. The Development and Evaluation of an Environmental Awareness Course Addressed to Student Tourist Guides in the Maltese Islands. In Handbook of Theory and Practice of Sustainable Development in Higher Education; Leal Filho, W., Brandli, L., Castro, P., Newman, J., Eds.; Springer International Publishing: Cham, Switzerland, 2017; Volume 1, pp. 333-347. [CrossRef]

98. Kioko, J.; Kiffner, C.; Phillips, P.; Patterson-Abrolat, C.; Katers, S. Driver knowledge and attitudes on vehicle collisions in Northern Tanzania. Trop. Conserv. Sci. 2015, 8, 352-366. [CrossRef]

99. Hurdle, J. Off-Road Drivers Still Battling Conservationists over Access to Pinelands. New Jersey SpotLight. 2019. Available online: https://www.njspotlight.com/2019/08/19-08-04-off-road-drivers-stillbattling-conservationists-over-access-to-pinelands/ (accessed on 24 August 2020).

(C) 2020 by the authors. Licensee MDPI, Basel, Switzerland. This article is an open access article distributed under the terms and conditions of the Creative Commons Attribution (CC BY) license (http://creativecommons.org/licenses/by/4.0/). 